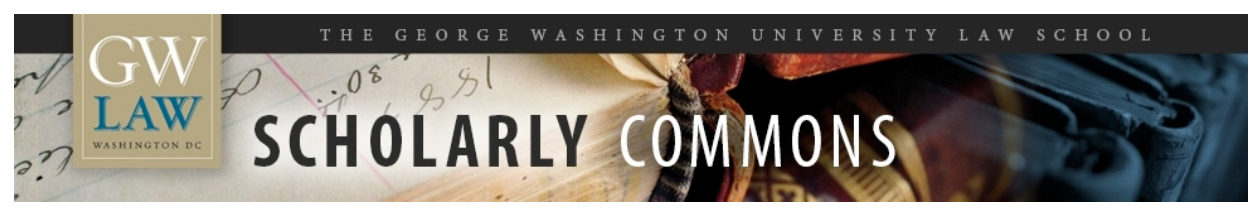

\title{
Remedying Societal Discrimination Through the Government's Spending Power
}

\author{
Michael Selmi \\ George Washington University Law School, mselmi@law.gwu.edu
}

Follow this and additional works at: https://scholarship.law.gwu.edu/faculty_publications

Part of the Law Commons

\section{Recommended Citation}

Michael Selmi, Remedying Societal Discrimination Through the Government's Spending Power, 80 N.C. L. Rev. 1575 (2002).

This Article is brought to you for free and open access by the Faculty Scholarship at Scholarly Commons. It has been accepted for inclusion in GW Law Faculty Publications \& Other Works by an authorized administrator of Scholarly Commons. For more information, please contact spagel@law.gwu.edu. 


\title{
REMEDYING SOCIETAL DISCRIMINATION THROUGH THE GOVERNMENT'S SPENDING POWER
}

\author{
by
}

\author{
MICHAEL L. SELMI ${ }^{*}$
}

TABLE OF CONTENTS

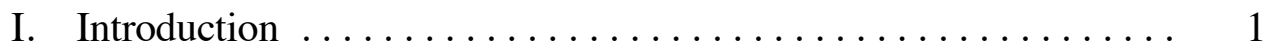

II. Understanding Societal Discrimination $\ldots \ldots \ldots \ldots \ldots \ldots \ldots$

A. The Supreme Court's Treatment of

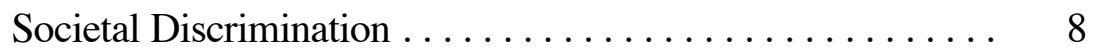

1. The Affirmative Action Cases ............ 8

2. Societal Discrimination \& Disparate Impact Theory .... 33

B. Defining Societal Discrimination ............. 35

1. Discrimination in the Air .............. 38

2. Societal Discrimination as Cumulative Acts ........ 39

III. The Spending Power . . . . . . . . . . . . . . . . . . . 49

A. The Recent Government Funding Cases $\ldots \ldots \ldots \ldots \ldots \ldots \quad 51$

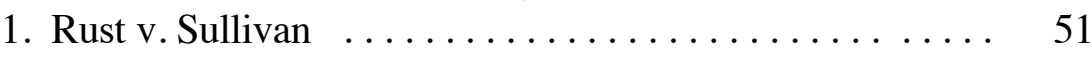

2. The NEA Controversy $\ldots \ldots \ldots \ldots \ldots \ldots \ldots \ldots 60$

3. The Rosenberger Case ............... 63

B. Government Spending in Other Contexts $\ldots \ldots \ldots \ldots \ldots 66$

1. South Dakota v. Dole .................. 67

2. The Patronage Cases $\ldots \ldots \ldots \ldots \ldots \ldots \ldots \ldots$

C. The Unconstitutional Conditions Doctrine .......... 71

IV. The Spending Power As Applied to Race . . . . . . . . . . . 77

A. The Contract Set-Asides . . . . . . . . . . . . . . . . . 79

1. Existing Set-Aside Programs \& Government Spending .................... 79

2. Reconfiguring the Set-Aside Provisions ......... 86

B. Other Means of Remedying Societal Discrimination ....... 96

1. Title VI \& the Disparate Impact Theory . . . . . . . . 96

2. Funding Integration Efforts $\ldots \ldots \ldots \ldots \ldots \ldots \ldots$

V. Conclusion .......................... 103

* Professor of Law, George Washington University Law School. A.B. Stanford University, J.D. Harvard Law School. I am grateful for comments I received on earlier versions from Jerry Barron, Bill Bratton, Roy Brooks, David Cole, Tom Dienes, Chip Lupu, Deborah Malamud, Molly McUsic, Wendy Parker, and Melissa Saunders. Kerri Scharr and Patti Soh have provided excellent research assistance and Leslie Lee was, as always, extremely helpful with library assistance. 


\section{INTRODUCTION}

The central dilemma posed by the Supreme Court's affirmative action jurisprudence is that most governmental programs are intended to remedy societal discrimination, and yet the Supreme Court has consistently failed to recognize a desire to remedy societal discrimination as a constitutionally adequate basis for race-conscious affirmative action programs. ${ }^{1}$ Stated somewhat differently, most governmental affirmative action is intended to remedy someone else's discrimination, but the Court will only allow governments to use race-conscious means to remedy their own discrimination. ${ }^{2}$ This is true even of those programs designed to foster diversity because the need to use race or gender-conscious means to attain diversity arises as a result of past societal discrimination. ${ }^{3}$

${ }^{1}$ I will discuss the cases in detail in section I.A, infra, but the leading cases are Regents of Ca. v. Bakke, 438 U.S. 265 (1978) (education affirmative action); Wygant v. Jackson Bd. of Education, 476 U.S. 267 (1986) (employment); City of Richmond v. Croson, 488 U.S. 469 (1989) (set-asides); Shaw v. Hunt, 517 U.S. 899 (1996) (redistricting).

${ }^{2}$ It is true that the Supreme Court has left some theoretical space for governments to remedy private discrimination. See Ian Ayres \& Frederick E. Vars, When Does Private Discrimination Justify Public Affirmative Action? 98 CoLum. L. Rev. 1577 (1998) (arguing that under certain circumstances the government can seek to remedy private discrimination). Lower courts, however, have generally interpreted Supreme Court doctrine to require proof of identified discrimination, committed or participated in, by the government before approving affirmative action plans. See, e.g., W.H. Scott Constr. Co. v. City of Jackson, 199 F.3d 206, $219\left(5^{\text {th }}\right.$ Cir. 2000) (requiring "particularized findings of discrimination within its various agencies"); Cohen v. Brown University, 101 F.3d 155, 171 ( $1{ }^{\text {st }}$ Cir. 1996) ("voluntary affirmative action plans cannot be constitutionally justified absent a particularized factual predicate demonstrating the existence of 'identified discrimination'”);Contractors Ass'n of Eastern PA v. City of Philadelphia, 91 F.3d 586, 596 ( ${ }^{\text {rd }}$ Cir. 1996) ("race-based preferences cannot be jusitifed by reference to past 'societal discrimination' in which the municipality played no material role"); Hopwood v. Texas, 78 F.3d 932, 950 ( $5^{\text {th }}$ Cir.), cert. denied, 518 U.S. 1016 (1996) ("the state's use of remedial racial classifications is limited to the harm caused by the specific state actor.").

${ }^{3}$ See Michael Selmi, The Facts of Affirmative Action, Reviewing the Shape of the River: Long-Term Consequences of Considering Race in College and University Admissions, 85 VA. L. 
Limiting the government's power to remedy societal discrimination has led to the invalidation of a wide range of race conscious programs, including perhaps most prominently the affirmative action policy at the University of Texas Law School. ${ }^{4}$ It is not too much to suggest that most, if not all, of these cases would have come out differently if the governmental entities had the power to remedy societal discrimination. Given the importance of the concept of societal discrimination to the Court's antidiscrimination doctrine, it is surprising that there has to date been no systematic exploration of the Court's jurisprudence. ${ }^{5}$ Equally surprising, the Court's proscription on remedying

REV. 697, 733 (1999) (book review) ("The importance of having leaders from diverse communities, or even the importance of positive interaction among different groups, has to do with past and present discrimination rather than any emphasis on diversity for the sake of diversity.").

4 See Hopwood v. Texas, 78 F.3d 932 (5 ${ }^{\text {th }}$ Cir.), cert. denied, 518 U.S. 1016 (1996) (invalidating use of race in admissions program for the University of Texas). The limitations imposed by the Court's doctrine has been instrumental in invalidating affirmative action programs in a wide range of areas, including efforts to encourage diversity within education. See Eisenberg v. Montgomery County Pub. Schools, 197 F.2d 123 (4 ${ }^{\text {th }}$ Cir. 1999), cert. denied, 529 U.S. 1019 (2000) (invalidating public school plan); Wessman v. Gittens, 160 F.3d 790 (1 $1^{\text {st }}$ Cir. 1998) (invalidating Boston school district racial balancing plan); Taxman v. Board of Education, 91 F.3d 1547 (3d Cir. 1996), cert. granted, 117 S.Ct. 2506, cert dismissed, 118 S.Ct. 595 (1997) (invalidating use of affirmative action in layoff determination); Podberesky v. Kirwan, 38 F.3d 147 (4 ${ }^{\text {th }}$ Cir. 1994), cert. denied, 514 U.S. 1128 (1995) (invalidating University of Maryland racially specific scholarships). Government's inability to remedy societal discrimination has also resulted in the invalidation of many contract set-aside programs. See, e.g., Associated General Contractors of Ohio v. Drabik, 214 F.3d 730 (6 ${ }^{\text {th }}$ Cir. 2000), cert. denied, 69 U.S.L.W. 3552 (2001) (invalidating Ohio set-aside program); W.H. Scott Constr. Co. v. City of Jackson, 199 F.3d 206 ( $5^{\text {th }}$ Cir. 2000) (invalidating Jackson's contract set-aside program); Monterey Mechanical Co. v. Wilson, 125 F.3d 702 (9 $9^{\text {th }}$ Cir. 1997) (invalidating California university's set-aside program); Engineering Contractors Ass'n of South Florida v. Metropolitan Dade County, 122 F.3d 895 (11 ${ }^{\text {th }}$ Cir. 1997), cert. denied, 523 U.S. 1004 (1998) (invalidating Dade County's contract program); Contractors Ass'n of Eastern PA v. City of Philadelphia, 91 F.3d 586 ( $3^{\text {rd }}$ Cir. 1996), cert. denied, 519 U.S. 1113 (1997) (Philadelphia's contract set-aside program invalidated as based on insufficient evidence).

5 Many commentators have acknowledged the importance of the limitation but typically do so without much further discussion. See T. Alexander Aleinikoff, The Case for Race Consciousness, 91 Colum. L. REv. 1060, 1096 (1991) ("Affirmative action programs may not attempt to remedy the 
societal discrimination has generally been accepted without significant challenge, and indeed little attention has been paid to whether there might be ways in which the government can take actions to eradicate societal discrimination.

In this article, I will address both of these issues. Although the concept of societal discrimination has been essential to the Court's affirmative action doctrine, the Court has never defined the term, other than through various negative inferences, nor has the Court satisfactorily explained its rationale for prohibiting governmental efforts aimed at remedying societal discrimination, a concept frequently contrasted with identified discrimination. ${ }^{6}$ A close review of the Court's cases will reveal that the Court has actually been more equivocal on the government's power to remedy societal discrimination than is generally assumed, and that the level of scrutiny the Court applies in a particular case has proved critical to determining whether the affirmative action program will be upheld. I will also suggest that when the concept of societal discrimination is defined concretely, it is clear that the government has a duty to remedy what is plainly a social problem, one that the government has often

effects of past and present 'societal discrimination."'); Angela P. Harris, Equality Trouble: Sameness \& Difference in Twentieth Century Race Law, 88 CALIF. L. REV. 1923, 2013 (2000) ("The Court has been adamant ... that the remedy of mere 'societal discrimination' is not a compelling state interest that justifies voluntary affirmative action programs.'); Kim Forde-Mazrui, The Constitutional Implications of Race-Neutral Affirmative Action, 88 GEO. L.J. 2331, 2341-42 (2000) ("Perhaps the greatest difficulty for affirmative action ... is the Supreme Court's rejection of 'societal discrimination' as a justification for racial classification."); Deborah C. Malamud, Affirmative Action, Diversity and the Black Middle Class, 68 U. Colo. L. REv. 939, 941 (1997) (“Anyone who has read the Supreme Court cases knows that the Court does not accept the remedying of past or present societal discrimination as an acceptable justification for affirmative action."); Reva Siegel, Why Equal Protection No Longer Protects: The Evolving Forms of Status-Enforcing State Action, 49 STAN. L. REV. 1111, 1143 (1997) (noting that the prohibition on remedying societal discrimination has severely "constrain[ed] legislatures from adopting policies designed to reduce race and gender stratification").

6 See infra section II.A \& B. 
played an important role in creating or perpetuating, although it is not always easy to document the precise nature of the government's role.

My primary purpose in this article will be to argue that consistent with the Court's existing doctrine the government can, and in fact does, make efforts to remedy societal discrimination. My argument will largely be based on a series of cases that have not previously been connected to governmental race-conscious programs, cases that involve various aspects of the government's spending powers. In particular, I will seek to borrow from the Court's jurisprudence involving governmentally imposed conditions on federal financial assistance. ${ }^{8}$ These cases have held in a variety of contexts that the government is constitutionally permitted to pursue legitimate political ends through its spending power, including on such controversial issues as discouraging abortions, ${ }^{9}$ and that the government can attain some ends indirectly through its spending power that it could not otherwise accomplish directly. ${ }^{10}$ Consistent with this line of cases, I will argue that the government should likewise be permitted to address lingering racial inequities through its spending power even when its principal objective is to remedy societal discrimination. If the government can choose not to fund abortions

7 See infra section II.B. Professor Abner Greene has recently argued that the government should use its means to pursue what the government chooses to define as the "good," rather than remaining neutral on important social and economic questions. See Abner S. Greene, The Government of the Good, 53 VAND. L. REV. 1 (2000). I agree with much of his argument but will for the most part eschew normative claims, though they will often be implicit and sometimes explicit - in my argument.

8 See in particular Rust v. Sullivan, 500 U.S. 173 (1991); NEA v. Finley, 524 U.S. 569 (1998). These and other cases are discussed in detail in section III, infra.

9 See Maher v. Roe, 432 U.S. 464 (1977); Harris v. McCrae, 448 U.S. 297 (1980); Rust v. Sullivan, 500 U.S. 173 (1991).

10 See, e.g., South Dakota v. Dole, 483 U.S. 203 (1987). 
through Medicaid ${ }^{11}$ and even go so far as to prohibit federal grant recipients from discussing abortion in their work ${ }^{12}$ as a means of pursuing a legitimate political goal, the government should be free to attach conditions to federal funds with an intent to remedy societal discrimination. In both instances, the government is seeking to pursue a political objective, and both circumstances call for the same level of judicial deference.

Governmental efforts designed to address societal discrimination may include promoting diversity through its contracting porgrams, promoting racial integration in housing and education, or other racially motivated, but not race conscious efforts. ${ }^{13}$ I will specifically suggest that existing government set-aside programs should be reconfigured so that the government would provide preferences to contractors based on the diversity of their workforces, rather than, as is currently the case, on the race or ethnicity of the ownership. Restructured in this way, the programs would entail a governmental policy preference for doing business with companies that have exemplary hiring records that helped redress the persistence of societal discrimination. Although my focus will largely be on federal programs since that is how the doctrine regarding the funding cases has largely developed, my argument should apply with equal force to local and state efforts aimed at remedying societal discrimination. ${ }^{14}$

11 See Maher v. Roe, 432 U.S. 464 (1977) and Harris v. McCrae, 448 U.S. 297 (1980).

12 See Rust v. Sullivan, 500 U.S. 173 (1991).

13 See section IV, infra.

14 As discussed in section II.A., the Supreme Court applies the same level of review to federal and state affirmative action programs. See Adarand Constructors, Inc. v. Pena, 515 U.S. 200 (1995). There is some possibility that a federal program would be upheld under a less strict form of review than might apply to state programs, largely as a result of the federal government's remedial powers under 
I will also demonstrate that the government indirectly accomplishes this goal currently through Title VI of the Civil Rights Act of $1964,{ }^{15}$ which requires federal contractors to refrain from racial discrimination, and has been construed to reach neutral practices that have disparate racial effects. ${ }^{16}$ Disparate impact claims are largely intended to remedy societal discrimination, and I will suggest that Title VI can be interpreted through the government's spending power to require the recipients of federal funds to take actions to remedy societal discrimination as a condition for the receipt of those funds. Under this theory, the government can require more of its fund recipients than the constitution requires, ${ }^{17}$ and it can do so with the express purpose of combating societal discrimination, despite the Supreme Court's frequent proclamations to the contrary.

This paper will proceed in three parts. Part II will discuss the Court's current doctrine

section 5 of the Fourteenth Amendment, and, indeed, the Tenth Circuit Court of Appeals recently upheld a federal set-aside program based on a form of strict scrutiny whereas no state or local program has yet survived a court's strict review. See Adarand Constructors v. Slater, 228 F.3d 1147 (10 ${ }^{\text {th }}$ Cir. 2000). The Supreme Court, however, has recently significantly restricted the government's section 5 remedial power. See Robert C. Post and Reva B. Siegel, Equal Protection By Law: Federal Antidiscrimination Legislation After Morrison and Kimel, 110 YALE L.J. 441 (2001). Whether the Court will permit a broader realm of federal efforts than it would accept for state or local programs remains to be seen, but my argument does not turn on the federal government's section 5 powers, and therefore will apply to all governmental efforts to remedy societal discrimination.

1542 U.S.C. $\$ 2000 d$ (Title VI). The federal government also prohibits sex discrimination in education among entities receiving federal financial assistance. See 20 U.S.C. $§ 1681$ et seq. There are a number of similarities between Title VI and Title IX, but in this article I will concentrate on race discrimination, for that is the context in which the Court's doctrine relating to societal discrimination has principally developed.

16 See Alexander v. Choate, 469 U.S. 287 (1985).

17 By virtue of a long-standing Executive Order, the Department of Labor requires federal contractors who receive federal contracts that exceed $\$ 25,000$ to engage in limited affirmative action efforts. See 41 C.F.R. $§ 60-1.1$ et seq. 
relating to remedying societal discrimination, describing the Court's concerns while highlighting some of the ironies and inconsistencies of that doctrine. In part III, I will craft my argument based on the government funding cases, and part IV will discuss what this doctrine means for the government's efforts to address societal discrimination.

\section{UNDERSTANDING SOCIETAL DISCRIMINATION.}

In this section, I will explore the Court's varied treatment of efforts to remedy societal discrimination. In one respect, the Court's attention to societal discrimination has been quite limited, as the Court has never adequately defined what it means by the term societal discrimination and its explicit discussion of the concept has been largely confined to two cases. ${ }^{18}$ However, although the Court's explicit consideration of societal discrimination has been surprisingly sparse, it has addressed the issue indirectly on a number of occasions, and indeed even though the Court has been quite hostile to the government's explicit efforts to remedy societal discrimination it has been far more receptive to indirect private and occasional governmental efforts designed to remedy societal discrimination. The first part of this section will provide an overview of how the Court has addressed societal discrimination - both directly and indirectly - and in the second part, I will turn to defining societal discrimination with an intent to sharpen the analytical focus on the issue.

\section{A. The Supreme Court's Treatment of Societal Discrimination.}

\section{The Affirmative Action Cases.}

The Court's first and most important discussion of societal discrimination arose in the famous affirmative action case of Regents of California v. Bakke, in which Allan Bakke challenged

18 See Regents of California v. Bakke, 438 U.S. 265 (1978), and Wygant v. Jackson Bd. of Educ., 476 U.S. 267 (1986), both of which will be discussed shortly. 
the preferential admissions policy administered by the medical school at the University of California at Davis. ${ }^{19}$ When the medical school opened in 1968, there were no African American or Latino students in the class of 100 even though minorities constituted approximately thirty percent of the state's population. ${ }^{20}$ Shortly thereafter the school sought to diversify its class by setting aside a fixed number of places for disadvantaged students, a classification that included applicants who were members of minority groups by virtue of their group membership, as well as others who petitioned for disadvantaged status. ${ }^{21}$ Given that the school had no history of its own that would explain the lack of minority students in the student body, it sought to justify its policy based on the history of discrimination African Americans and other minorities had encountered in California and throughout the nation; in other words, it sought to justify its policy as necessary to address the effects of societal discrimination. However, in what has become a critical and oft-repeated legal strategy, the school did not document that history but instead largely assumed it based on the exclusion of minorities from the school's entering class. $^{22}$ The absence of minorities in the class, the argument went, was obviously the direct product of

19438 U.S. 265 (1978). One year earlier the Court upheld a federal statute that provided greater retirement benefits to women than to men. The statute was not justified on the basis that the retirement system had discriminated against women but that the private labor market had for many years disadvantaged women. See Califano v. Webster, 430 U.S. 313 (1977). Even though the Court never used the term societal discrimination in it decision, the concept arguably applied.

20438 U.S. at 272 (noting that the original class of 100 "contained three Asians but no blacks, no Mexican-Americans, and no American-Indians.").

21 See Michael Selmi, The Life of Bakke: An Affirmative Action Retrospective, 87 GEO. L.J. 981, 985 (1999). For a comprehensive discussion of the Bakke case see JOEL DREYFUSS \& Charles Lawrence III, The Bakke Case: The Politics of Inequality (1979).

22 See Selmi, supra note 21, at 989 (discussing treatment of discrimination in the Supreme Court briefs). 
societal discrimination, so obvious that it did not require any additional proof or discussion.

In contrast, the Department of Justice, and several other amici, all made a concerted effort to document the history of discrimination against minorities in California as a way of explaining why so few minority candidates had applied or been admitted to the state medical schools. ${ }^{23}$ Additionally, the United States argued that the state of California should be permitted to take affirmative measures to remedy societal discrimination, although the government did not use that term in its brief. Contending that it was impractical to restrict a university to remedying its own discrimination, the government argued,

"The principal. . . justification [for an affirmative action program] . . is that racial discrimination elsewhere in society makes it difficult to fairly evaluate the abilities and promise of each new applicant without taking race into account in evaluating his credentials. ... It follows that no institution is limited to rectifying only its own discrimination. If it were, the consequences of discrimination that spilled over from the discriminator to society at large would be irreparable, and the victims of discrimination would be doomed to suffer its consequences without even the prospect of voluntary assistance. ${ }^{24}$

As is well-known, the Bakke case produced a sharply fractured Court, reflected in six complicated opinions, none of which conveyed the sentiment of a majority of the Court. Among the six opinions, only Justice Powell's directly addressed the important question of whether the government

23 The Justice Department documented the discrimination that had affected minority students both within and outside of California, as well as the discrimination black applicants faced in applying to medical school. See Brief for the United States as Amicus Curiae, Bakke, at 42-46. In addition, the government documented the discrimination black doctors faced in obtaining jobs and joining medical societies. Id. at 46-47. The brief filed by three black professional groups - the National Medical Ass'n, the National Bar Ass'n, and the National Ass'n for Equal Opportunity in Higher Education provided the most extensive discussion of discrimination within the state of California that justified the special admissions program. See Selmi, supra note 21, at 989.

24 Brief for the United States, supra note 23, at 39. 
could take action to remedy societal discrimination. ${ }^{25}$ Recognizing that one of the goals of the special admissions program at the medical school was to "counter[] the effects of societal discrimination," Justice Powell nevertheless found this interest insufficiently compelling to justify infringing on the rights of those who did not qualify for the special admissions program. ${ }^{26}$ He wrote,

"The State certainly has a legitimate and substantial interest in ameliorating, or eliminating where feasible, the disabling effects of identified discrimination. The line of school desegregation cases, commencing with Brown attests to the importance of this state goal and the commitment of the judiciary to affirm all lawful means toward its attainment. In the school cases, the States were required by court order to redress the wrongs worked by specific instances of racial discrimination. That goal was far more focused than the remedying of the effects of 'societal discrimination,' an amorphous concept of injury that may be ageless in its reach into the past."'27

Central to Justice Powell's argument was a sense that permitting the medical school to remedy "societal discrimination" would allow the school to exercise its unfettered discretion, or perhaps its political power, to privilege those it arbitrarily viewed as the victims of societal discrimination. Allowing the program to stand, he argued, would "convert a remedy heretofore reserved for violations of legal rights into a privilege that all institutions throughout the Nation could grant at their pleasure to whatever groups are perceived as victims of societal discrimination. ${ }^{228}$ Earlier in his Opinion, Justice Powell noted that

25 Justice Brennan's opinion, concurring and dissenting, noted that Title VI did not "bar the preferential treatment of racial minorities as a means of remedying past societal discrimination to the extent that such action is consistent with the Fourteenth Amendment." Bakke, 438 U.S. at 328 (Brennan, J., concurring and dissenting). In his separate opinion, Justice Marshall likewise noted that there was ample precedent "for the conclusion that a university can employ race-conscious measures to remedy past societal discrimination, without the need for a finding that those benefited were actually victims of discrimination.” Id. at 399 (Marshall, J., concurring and dissenting).
${ }^{26}$ Id. at 306.
27 Id. at 307.
28 Id. at 310. 
"the 'white' majority itself is composed of various minority groups, most of which can lay claim to a history of prior discrimination at the hands of the State and private individuals, ${ }^{29}$ adding that the Court would likely be asked "to evaluate the extent of prejudice and consequent harm suffered by various minority groups. Those whose societal injury is thought to exceed some arbitrary level of tolerability then would be entitled to preferential classifications at the expense of individuals belonging to other groups., 30

Professor Keith Bybee has recently placed Justice Powell's opinion in context by arguing that Powell's concerns relating to the potential elasticity of societal discrimination were strongly influenced by a distinct political theory tied to a particular but by no means universal understanding of interest group politics. ${ }^{31}$ Under this interpretation, which was reflected at the time in the writings of Richard Posner among others, discrimination was seen as part of the battle among shifting political alliances, where "[d]iscrimination is no longer located along any single axis; instead it is exercised along a variety of different axes, dictated by the ebb and flow of political rivalry." ${ }^{22}$ Yet, as Bybee notes, this theory in its pure form overlooks the historical fact that political alliances do not shift in an endless fashion, but more often reflect a biased operation, one in which some groups repeatedly come out ahead of others. It is noteworthy that this critique of interest group politics existed in the political science literature at the time Bakke was decided but Justice Powell appeared either unaware or

\section{Id. at 295.}

30 Id. at 296-97 (footnote omitted).

31 See Keith J. Bybee, The Political Significance of Legal Ambiguity: The Case of Affirmative Action, 34 LAw \& Soc'y Rvw . 263, 277 (2000).

32 Id. at $278 \&$ n. 18. 
unattracted to the critique, preferring instead to ascribe to an older and stronger version of interest group politics. ${ }^{33}$

Not only was Justice Powell influenced by a particular political theory, but his slippery slope argument that it would be difficult to discern classifications that were properly supported by past discrimination seemed wholly inconsistent with the Supreme Court's Equal Protection jurisprudence. The Supreme Court has long relied on tiers of scrutiny in the Equal Protection context to evaluate legislative classifications because the nation's history of discrimination has affected groups in varied ways, and the Court had never previously suggested that it would be difficult to distinguish the harm those discriminated based on race suffered from discrimination based on other characteristics such as age. ${ }^{34}$ Federal statutes likewise make clear distinctions among those who are deserving of protection and those who are not, ${ }^{35}$ and it seems an unusually naive argument to suggest that allowing affirmative action in the context of race would inevitably lead to affirmative action in a host of other undefined and arbitrary contexts. In this way, Justice Powell's argument seems quite disingenuous, though as we will see it has also been deeply influential. Indeed, Justice Powell's discussion - even though it was not

${ }^{33}$ Id. at 282-83. The role of interest groups and shifting coalitions continues to occupy a contested place when race is implicated, in particular in the area of voting rights litigation where African Americans and Latinos have often been unable to forge coalitions that would enable the group to elect representatives of their choosing, to use the statutory language. For a discussion of the limits of racial justice in a majoritarian system see LANI GUINIER, THE TYRANNY OF THE MAJORITY (1994).

34 See Massachusetts Bd. of Retirement v. Murgia, 427 U.S. 307 (1976) (per curiam) (applying rationality review to age discrimination claim under Equal Protection clause).

35 Indeed, federal statutes are remarkably consistent regarding which groups are deserving of protection, and race is invariably a protected category, whereas age is not always included within the statutory ambit. 
joined by any other member of the Court - continues to resonate, having been repeated in various forms and contexts on many occasions over the last twenty-five years, and is singularly responsible for the way in which the Court has considered the issue of societal discrimination. ${ }^{36}$

Another noteworthy feature of Justice Powell's discussion is that he never sought to define societal discrimination, other than through negative references and juxtaposition. On several occasions, Justice Powell distinguished societal discrimination from "identified discrimination" ${ }^{\text {"37 }}$ and "specific instances of racial discrimination" 38 implying that societal discrimination is defined by the absence of a provable claim. But his argument that "societal discrimination" could be applied to any group consistent with the interests of policymakers suggests that he may not have considered societal discrimination a form of discrimination at all, a fact reflected in his reference to those who benefitted by preferential policies as the "perceived victims of "societal discrimination."39 In contrast to his skepticism towards societal discrimination as providing a legitimate basis for governmental action, Justice Powell

${ }^{36}$ It is frequently noted that Justice Powell's opinion garnered no other votes, and much has been made of the Fifth Circuit Court of Appeal's determination that Bakke is no longer good law. See Hopwood v. Texas, 78 F.3d 932, 942 ( $5^{\text {th }}$ Cir.), cert. denied, 518 U.S. 1016 (1996). However, two other appellate courts have recently suggested that Justice Powell's opinion continues to provide the controlling guidance on affirmative action in education. See Smith v. University of Washington Law School, 233 F.3d 1188, 1197 ( ${ }^{\text {th }}$ Cir. 2000) (holding Justice Powell's opinion in Bakke offers best guidance on constitutional standards for educational affirmative action program); Wessman v. Gittens, 160 F.3d 790, 800 ( $1^{\text {st }}$ Cir. 1998) (declining to follow Fifth Circuit's interpretation). Commentators likewise continue to treat Justice Powell's opinion as influential. See Peter J. Rubin, Reconnecting Doctrine and Purpose: A Comprehensive Approach to Strict Scrutiny After Adarand and Shaw, 149 U. PA. L. Rev. 1, 34 (2000) (defining Justice Powell's Bakke opinion as "the controlling opinion in what at least for now remains the Supreme Court's leading affirmative action case").

\footnotetext{
${ }^{37}$ Bakke, 438 U.S. at 309.

${ }^{38}$ Id. at 307.

${ }^{39}$ Id. at 309.
} 
was undeniably concerned with the rights of those who were unable to take advantage of the special admissions program "who bear no responsibility for whatever harm the beneficiaries of the special admissions program are thought to have suffered." 40 As should be apparent, these are classic antiaffirmative action arguments that were becoming prominent at the time Bakke was decided. ${ }^{41}$

Although Justice Powell's opinion set the groundwork for what would ultimately become the Court's position some years later, and has guided the Supreme Court's affirmative action doctrine ever since, Justice Brennan's Bakke opinion, which contended that remedying societal discrimination could provide a constitutionally justifiable basis for affirmative action programs, garnered four votes. ${ }^{42}$ However, in what was an otherwise lengthy opinion, Justice Brennan's treatment of societal discrimination was relatively brief. He noted that it was appropriate for the University to

${ }^{40} I d$. at 310.

41 See, e.g., Nathan Glazer, Affirmative Discrimination (1975); Richard A. Posner, The DeFunis Case and the Constitutionality of Preferential Treatment of Racial Minorities, 1974 Sup. CT. Rev. 1; see also Antonin Scalia, The Disease as Cure: "In Order to Get Beyond Racism, We Must First Take Account of Race,” 1979 WASH. U. L.Q. 147. Although Justice Powell clearly appeared hostile to the idea of remedying societal discrimination through the quota program at issue in the Bakke case, the strength of his hostility was less clear in light of his vote to approve the consideration of race in the admissions process as one factor among many. Bakke, 438 U.S. at 318. To be sure, he justified the inclusion of race under the general rubric that universities should be able to create a diverse student body, (id. at 312 (Opinion of Powell, J.)), but the lack of diversity that necessitated the special admissions program was almost certainly attributable to societal discrimination, a point that was overlooked in Justice Powell's opinion, and which offered universities an opportunity to address societal discrimination that would otherwise have limited the diversity of the class.

42 Justice Brennan's opinion was joined by Justices White, Blackmun and Marshall. Justice Marshall's separate opinion, which detailed the need for affirmative action programs in more detail than did Justice Brennan's, reached the same conclusion as Justice Brennan, namely that there was "ample support for the conclusion that a university can employ race-conscious measures to remedy past societal discrimination, without the need for a finding that those benefitted were actually victims of that discrimination." Bakke, 438 U.S. at 387 (opinion of Marshall, J.). 
conclude that underrepresentation of minorities in medicine was the "consequence of a background of deliberate, purposeful discrimination against minorities in education and in society generally, ${ }^{, 43}$ and he concluded that the school's "articulated purpose of remedying the effects of past societal discrimination is ... sufficiently important to justify the use of race-conscious admissions programs where there is a sound basis for concluding that minority underrepresentation is substantial and chronic, and that the handicap of past discrimination is impeding access of minorities to Medical School."44 Without noting the standard of review he was applying, Justice Brennan took a critical step that presaged future doctrinal developments. By labeling the interest of remedying societal discrimination as "important" he suggested that it would satisfy the Court's intermediate level of scrutiny, though perhaps not its strict standard which generally requires a compelling governmental interest. ${ }^{45}$ As will be discussed in more detail below, governmental efforts to remedy societal discrimination have generally been upheld when they are freed from the Court's strict scrutiny, even though the Court has not always made a clear connection to the level of scrutiny it was applying.

The importance of the Court's scrutiny was evident in a case that arose just two years after Bakke was decided. In Fullilove v. Klutznick, ${ }^{46}$ the Supreme Court upheld a federal contract set-aside program without any mention of societal discrimination, although it was societal discrimination

43 Bakke, 438 U.S. at 370-71 (Opinion of Brennan, J.).

${ }^{44}$ Id. at 362 (Opinion of Brennan, J.).

45 See Mississippi University for Women v. Hogan, 458 U.S. 718, 724 (1982) (gender classification must serve "important governmental objectives" and "the discriminatory means [must be] substantially related to the achievement of those objectives.").

46448 U.S. 448 (1980). For an extensive discussion of the Fullilove case see Drew S. Days, III, Fullilove, 96 Yale L.J. 453 (1987). 
that provided the underlying motive for the government's contracting program. Fullilove involved a federal program that required ten percent of federal highway dollars be distributed to minority contractors. ${ }^{47}$ As noted by the Court, the legislative record plainly identified societal discrimination as the program's rationale: "Currently, we more often encounter a business system which is actually racially neutral on its face, but because of past overt social and economic discrimination is presently operating, in effect, to perpetuate these past inequities. ${ }^{38}$ As a result of that societal discrimination, the program sought to direct funds into the minority community to remedy the demonstrated past inequities. ${ }^{49}$ These inequities as detailed in the legislative record were the product of social and economic forces, and were not directly linked to the actions of the federal government, yet the Supreme Court upheld the program primarily as a valid effort to eradicate the "present effects of past discrimination. ${ }^{50}$

The Court was again, however, unable to forge a majority opinion, and in this instance Chief Justice Burger wrote a plurality opinion for two other members of the Court that is principally notable for its obscurity. The plurality eschewed any particular standard of review, concluding instead that "the MBE provision would survive judicial reveiw under either 'test' articulated in the several

47448 U.S. at 454.

${ }^{48} I d$. at 466 n.48 (quoting H.R. Rep. No. 94-1791, p. 182). In his concurring opinion, Justice Powell cited this language as well (id. at 505) and he went further to conclude that "the legislative history ... demonstrates that Congress reasonably concluded that private and governmental discrimination had contributed to the negligible percentage of public contracts awarded to minority contractors." Id. at 503 (footnote omitted)
${ }^{49} I d$. at 459.
${ }^{50}$ Id. at $475-83$. 
Bakke opinions, ${ }^{, 51}$ and likewise failed to ground the decision in any particular constitutional power, relying to varying degrees on the Spending Clause, Commerce Clause, and section 5 of the Fourteenth Amendment. ${ }^{52}$ The plurality did, however, acknowledge Congress' power under the Spending Clause "to further broad policy objectives by conditioning receipt of federal moneys upon compliance with federal statutory and administrative directives. ${ }^{.53}$ In separate concurring opinions, Justices Powell and Marshall applied their earlier opinions from Bakke in upholding the program, Justice Powell under a standard of strict scrutiny while Justice Marshall applied what would be equated to an intermediate level of review. ${ }^{54}$ Counting up the Justices and putting the different opinions together, it appears that at this point in the Court's doctrine a majority of the Court was willing to allow the federal government to use race conscious means to remedy societal discrimination.

Yet, it is not so easy to reconcile the Court's treatment of the government's power to

51448 U.S. at 492 (plurality opinion).

${ }^{52} I d$. at 473-76 (plurality opinion).

${ }^{53} I d$. at 474 (plurality opinion). In one sense, it might be said that the plurality rested its decision on the Spending Clause, given that the Spending Clause was initially mentioned as the proper constitutional authority. Yet, the plurality then noted that the Spending Clause reaches at least as far as the Commerce Clause, and that insofar as Congress could have "achieved its objectives under the Commerce Clause ... the objectives ... are within the scope of the Spending power." Id. at 476 (plurality opinion).

${ }^{54}$ See id. at 496 (Powell, J., concurring) ("I join the [plurality] opinion and write separately to apply the analysis set forth by my opinion in ... Bakke); id. at 517 (Marshall, J., concurring) ("My resolution of the constitutional issue in this case is governed by the separate opinion I coauthored in ... Bakke). As in Bakke, Justice Powell wrote only for himself, while Justices Brennan and Blackmun joined Justice Marshall's concurring opinion. Justice Stewart filed a dissenting opinion, joined by Justice Rehnquist, which largely repudiated nonremedial race conscious measures, and Justice Stevens filed a dissenting opinion arguing against remedial affirmative action. See id. at 522 (Stewart, J., dissenting); $i d$. at 532 (Stevens, J., dissenting). 
remedy societal discrimination in Fullilove with the Court's prior discussion in Bakke, especially since the Fullilove plurality only cursorily mentioned its earlier decision at the very end of its opinion and never fully connected the two decisions. There are, however, several possible ways to distinguish the programs at issue in the two cases. One potential difference has already been noted: Congress created a legislative record to support its contracting program, whereas the Davis Medical School established its program without the benefit of any legislative or administrative findings. However, this distinction ultimately proves unpersuasive because the findings in Fullilove did not directly implicate the federal government in the industry's discriminatory practices, and the presence of a legislative record would not adequately overcome the constitutional concerns expressed by Justice Powell in his Bakke opinion regarding the amorphous nature of societal discrimination. ${ }^{55}$

The more significant difference between the two cases involved the abilities of the federal and state governments to remedy societal discrimination. The plurality decision in Fullilove rested on the federal government's power to remedy discrimination through the Spending Clause as interpreted through the Commerce Clause, the latter involving a power not available to state governments, and as a supporting theory, the plurality likewise noted Congress' remedial power under section 5 of the Fourteenth Amendment. ${ }^{56}$ This difference in remedial power rendered the federal program subject to a higher level of judicial deference, though as was also true in Bakke the Court failed to reach a consensus on what the appropriate level of judicial scrutiny was. Subsequently, commentators widely interpreted Fullilove as applying an intermediate level of scrutiny, and that level

\footnotetext{
55 See supra text accompanying notes 27-30.

56 Fullilove, 448 U.S. at 474-76.
} 
of scrutiny appeared important, particularly as the Court's doctrine progressed, to upholding the program. ${ }^{57}$ At the same time, the Court's failure directly to address the government's role in remedying societal discrimination, left the question largely unsettled, and it was another seven years before the Court again directly confronted the question of the government's power to remedy societal discrimination.

On this occasion the Court began to coalesce around a position rejecting societal discrimination as a remedial basis for affirmative action, although the Court was still unable to forge a majority opinion. The case, Wygant v. Jackson Board of Educ., ${ }^{58}$ involved the efforts of a school board to preserve the effects of its recent affirmative action hiring by placing a limit on the layoffs of minority teachers. Pursuant to the collective bargaining agreement negotiated by the teachers' union, the Board of Education agreed to forego seniority-based layoffs in order to retain a certain percentage

57 See Marci A. Hamilton \& David Schoenbrod, The Reaffirmation of Proportionality Analysis Under Section 5 of the Fourteenth Amendment, 21 CARdozo L. REv. 469, 477 (1999) ("the Court took its cue from Fullilove ... and held in MetroBroadcasting v. FCC that intermediate scrutiny" was appropriate); J. Edmond Nathanson, Congressional Power to Contradict the Supreme Court's Constitutional Decisions: Accommodation of Rights in Conflict, 27 WM . \& MARY L. REV. 331, 347 (1986) ("In Fullilove, the Court reviewed an affirmative action plan under what apparently was an intermediate level of scrutiny.”); Laura M. Padilla, Intersectionality \& Positionality: Situating Women of Color in the Affirmative Action Dialogue, 66 FordHAM L. REv. 843, 929 n.305 (1997) (defining Fullilove as applying intermediate level of scrutiny). As a number of commentators have pointed out, the plurality opinion in Fullilove suggested that the program under consideration could withstand even the Court's strict level of scrutiny, which might suggest that the level of scrutiny was not dispositive at least at the time of the Court's decision. See Neal Devins, Affirmative Action After Reagan, 68 TEX. L. REV. 353, 375 (1989) (defining Fullilove as having applied strict scrutiny). While it is true that the plurality intimated that the program could be withheld under any standard, it is likewise true that as the Court's doctrine progressed, culminating in its decision in MetroBroadcasting v. FCC, the standard of review applied in Fullilove became increasingly important and was increasingly treated as equivalent to intermediate review. See infra at text accompanying notes 87-92.

58476 U.S. 267 (1986). 
of minority faculty teachers so as not to lose the salutary effects of its recent minority hiring. ${ }^{59}$ The school board sought to justify its program on several different grounds, including a desire to remedy societal discrimination. ${ }^{60}$ Writing for a plurality of the Court, and applying a test of strict scrutiny, Justice Powell rejected this justification: "This Court never has held that societal discrimination alone is sufficient to justify a racial classification. Rather the Court has insisted upon some showing of prior discrimination by the governmental unit involved before allowing limited use of racial classifications in order to remedy such discrimination.'

Justice Powell's rationale for this categorical rule focused on the difficulty of defining societal discrimination with precision, an argument that largely repeated the themes he had originally developed in his Bakke opinion. "Societal discrimination, without more," Justice Powell wrote, "is too amorphous a basis for imposing a racially classified remedy .... No one doubts that there has been serious racial discrimination in this country. But as the basis for imposing discriminatory legal remedies that work against innocent people, societal discrimination is insufficient and over expansive. In the absence of particularized findings, a court could uphold remedies that are ageless in their reach into the past, and timeless in their ability to affect the future. ${ }^{92}$ In a footnote, Justice Powell also made what

59 Id. at 272.

${ }^{60} I d$. at 274. There was also, however, evidence of past discrimination as well as evidence that the School Board voluntarily agreed to the affirmative action plan to avoid being sued for discrimination. See id. at 287 (O’Connor, J., concurring) (“The Michigan Civil Rights Commission determined that the evidence before it supported the allegations of discrimination on the part of the Jackson School Board, though that determination was never reduced to formal findings because the School Board ... voluntarily chose to remedy the perceived violation.”)

${ }^{61} I d$. at 274 (plurality opinion).

${ }^{62} I d$. at 276. 
might be considered a contradictory, but revealing, argument, namely that societal discrimination was too pervasive to serve as the basis for governmental relief and, if allowed, would effectively permit any and all governmental efforts. ${ }^{63}$ Justice O'Connor, who provided the critical fifth vote to invalidate the layoff plan at issue in Wygant, devoted only one sentence of her concurring opinion to the goal of remedying societal discrimination, agreeing with the plurality's conclusion that "societal discrimination, that is, discrimination not traceable to its own actions, cannot be deemed sufficiently compelling to pass constitutional muster under strict scrutiny. ${ }^{\circ 4}$

Although the Court's discussion of the government's role of remedying societal discrimination was brief, the Wygant case effectively set the tone for a broad limitation on the government's remedial power, and the case remains deeply influential and widely cited. ${ }^{65}$ Yet, harkening back to the Court's doctrinal reverberations in Bakke and Fullilove, the very next Term the Court approved a gender-based affirmative action plan that was intended to remedy a manifest
${ }^{63}$ See id. at 278 n.5.
${ }^{64} \mathrm{Id}$. at 288 (O’Connor, J., concurring).

${ }^{65}$ For cases relying on Wygant to the effect that a desire to remedy societal discrimination will not support an affirmative action plan, see, e.g., Eisenberg v. Montgomery County Pub. Schs., 197 F.3d 123 ( $4^{\text {th }}$ Cir. 1999); Wessman v. Gittens, 160 F.3d 790 ( $~^{\text {st }}$ Cir. 1998); Cohen v. Brown University, 101 F.3d 155, 171 ( $1^{\text {st }}$ Cir. 1996); Middleton v. Flint, 92 F.3d 396 ( $6^{\text {th }}$ Cir. 1996); Taxman v. Board of Educ., 91 F.3d 1547, 1560 ( $3^{\text {rd }}$ Cir. 1996); Contractors Ass'n v. City of Philadelphia, 91 F.3d 586 (3d Cir. 1996); Hayes v. North State Law Enforcement Officers Ass'n, 10 F.3d 207 ( $4^{\text {th }}$ Cir. 1993); Stuart v. Roche, 951 F.2d 446, 451 ( $1^{\text {st }}$ Cir. 1991); United States v. Starrett City Assoc., 840 F.2d 1096 (2d Cir. 1988). The Wygant case was complicated by the introduction of what is generally referred to as "the role model theory" as one of the school board's justifications for its affirmative action policy. The school board argued that it was necessary to retain minority teachers to provide minority students with appropriate role models, a theory the Court found particularly pernicious in that it seemed to assume that black students could benefit only from having black role models, an argument the Court perceived as a form of racial stereotyping. Wygant, 476 U.S. at 276. 
imbalance in the agency's workforce, an imbalance that was attributable to societal discrimination. The case, Johnson v. Transportation Agency of Santa Clara County, arose when the agency hired its first female dispatcher in the early 1980s, choosing her over a male employee who had scored modestly higher on a subjective employment examination that had been used to qualify individuals for the promotional position. ${ }^{66}$ When the male employee sued under Title VII of the Civil Rights Act of 1964, the agency justified its decision by arguing that it was seeking to remedy what the Court labeled a "manifest imbalance" in its workforce, namely the fact that no woman had ever held one of the 238 skilled positions within the agency. ${ }^{67}$ Importantly, the agency did not contend that the imbalance had been caused by its own actions but instead suggested that the imbalance was the product of undefined social forces. ${ }^{68}$ While the Court majority never used the term societal discrimination, it was plain that Santa Clara County was attributing the deficit to societal discrimination, and adopted its affirmative action plan as a means to counter that discrimination.

In a sharply contested decision, the Court upheld the agency's decision to take gender into account in the promotional decision, impliedly affirming the County's efforts to remedy societal

66480 U.S. 616 (1987). One of the interesting, and often overlooked, aspects of the case is that the test score differences at issue were trivially different from one another, and not likely to have reflected any significant differences in ability. See Michael Selmi, Testing for Equality: Merit, Efficiency, and the Affirmative Action Debate, 42 UCLA L. Rev. 1251, 1252, 1274 (1995). The government argued throughout the litigation that the candidates were roughly equivalent in their qualifications. See Melvin I. Urofsky, A Conflict of Rights: The SuPReme Court AND AFFirmative ACTION 12 (1991)

${ }^{67}$ Johnson, 480 U.S. at 621.

${ }^{68}$ Urofsky, supra note 66 , at 61. 
discrimination. ${ }^{69}$ Perhaps to avoid some of the concerns regarding the elasticity of the concept of societal discrimination, the Court sought to confine the governmental efforts to those that were intended to remedy a "manifest imbalance" in the workforce, which was further defined to apply to traditionally segregated job categories where there was an adequate available labor force. ${ }^{70}$ These limitations may have appeased the concerns of Justice Powell, who joined the majority's opinion, ${ }^{71}$ but they struck a cord with Justice Scalia who filed a scathing dissenting opinion in which he emphasized what he perceived to be an apparent break with the Court's recent precedent. Indeed, he suggested that " $[\mathrm{t}] \mathrm{he}$ most significant proposition of law established by today's decision is that racial or sexual discrimination is permitted under Title VII when it is intended to overcome the effect, not of the employer's own discrimination, but of societal attitudes . ..,72

Given the lack of any record documenting the agency's own discrimination, Justice Scalia seems correct in his assessment, but there are two potential facets that might distinguish the Johnson case. As noted earlier, Johnson involved a challenge under Title VII rather than the

${ }^{69}$ Johnson, 480 U.S. at 621 .

${ }^{70} I d$. at 632 .

${ }^{71}$ Justice Brennan wrote the majority opinion for five members of the Court, including Justice Powell. Justice Stevens and O'Connor filed concurring opinions, and Justice Scalia, in his first Term on the Court, filed a dissenting opinion.

${ }^{72} I d$. at 664 (Scalia, J., dissenting). It seems safe to say that Justice Scalia believed that the primary cause of the workforce imbalance was not discrimination but was rather the product of choice, although choice that was perhaps influenced by societal attitudes. He wrote: "It is absurd to think that the nationwide failure of road maintenance crews ... to achieve the Agency's ambition of 36.4\% female representation is attributable primarily, if even substantially, to systematic exclusion of women eager to shoulder pick and shovel. It is a 'traditionally segregated job category' ... in the sense that, because of longstanding social attitudes, it has not been regarded by women themselves as desirable work." 480 U.S. at 668 (Scalia, J., dissenting) (emphasis in original). 
constitution, and it may be that the remedial power under Title VII is broader than what is permitted under the constitution. Indeed, in Johnson there was some dispute between the majority and dissenting opinions on the scope of Title VII, and the majority obliquely suggested that the statute's remedial reach was not necessarily coextensive with the constitutional requirements. ${ }^{73}$ But this was an issue the Court did not definitively resolve, and more recently lower courts have adopted the position articulated in Justice Scalia's dissenting opinion that the constitutional and statutory standards are in congruence at least as applied to public employers. ${ }^{74}$

A better understanding of Johnson is that a governmental desire to remedy societal discrimination can satisfy the Court's intermediate level of scrutiny, which suggests that it is an important but not compelling interest in the Court's constitutional schema. The Supreme Court has long applied an intermediate level of review to gender classifications, under which a governmental classification will

73 See 480 U.S. at 627 n.6. In contrast, Justice Scalia argued that Title VII could not permit broader remedial authority than the constitution allowed. Id. at 664-67 (Scalia, J., dissenting).

74 See Taxman v. Board of Education, 91 F.3d 1547 (3d Cir. 1996), cert. granted, 117 S.Ct. 2506, cert dismissed, 118 S.Ct. 595 (1997) (treating standards under Title VII and the Equal Protection Clause as the same); Cygnar v. City of Chicago, 865 F.2d 827, 838-40 ( $7^{\text {th }}$ Cir. 1989) (same); see also George Rutherglen \& Daniel R. Ortiz, Affirmative Action Under the Constitution and Title VII: From Confusion to Convergence, 35 UCLA L. REV. 467 (1988) (arguing that the two standards should be treated similarly). A number of courts have faithfully sought to follow the suggestion in Johnson that Title VII and the Equal Protection Clause need not be treated as having the same reach with respect to affirmative action plans. To the extent courts have been able to discern a difference, they tend to focus on the "manifest imbalance" in the workforce, which may be sufficient to justify a plan under Title VII but not the constitution. See Smith v. Virginia Commonwealth Univ., 84 F.3d 672, $686 \mathrm{n} .4$ ( $4^{\text {th }}$ Cir. 1996) (existence of a "manifest imbalance" may justify remedial efforts under Title VII). 
be upheld if it is substantially related to an important governmental objective. ${ }^{75}$ Viewed in this light, the Courts' constitutional doctrine may have influenced its statutory interpretation in the Johnson case, even though under Title VII the protected classifications are generally afforded the same level of review. ${ }^{76}$ Ultimately, it is difficult to know whether the Court was influenced by an intermediate standard of review. On the one hand, the Court did not emphasize the standard of scrutiny it was applying, just as it typically does not specify a standard in the Title VII context. At the same time, finding that the plan was justified under a lower level of review would help reconcile the Court's doctrine, in particular would help reconcile the case with Wygant which occurred only a year earlier and is otherwise difficult to square with the Court's holding in Johnson.

This reading is also consistent with the Court's consideration of societal discrimination in more recent cases involving contract set-asides. In City of Richmond v. J.A. Croson, ${ }^{77}$ the Supreme Court struck down the City of Richmond's contract set-aside plan where the city required prime contractors to subcontract at least thirty percent of the contract to firms that qualified as minority business enterprises ${ }^{78}$ For the first time in the Court's complicated affirmative action doctrine, a majority of the Court applied a strict level of scrutiny to the city's plan, and found that the city had failed

75 See Craig v. Boren, 429 U.S. 190 (1976) (establishing intermediate scrutiny as the appropriate level of review for gender classifications); Califano v. Webster, 430 U.S. 313 (1977) (applying the standard established in Boren).

76 There are some limited exceptions. For example, race cannot provide the basis for a bona fide occupational qualification defense (see 42 U.S.C. § 703e-2) and employers have an accommodation defense to a claim based on religious discrimination that is not available for race, gender or national original. See Trans World Airlines v. Hardison, 432 U.S. 63 (1977).

77488 U.S. 469 (1989).

${ }^{78} I d$. at 481 . 
to justify the need for its program. ${ }^{79}$ As had been true of all the previous affirmative action cases, the City of Richmond had failed to document its own discrimination to explain why so few city contracting dollars went to minority contractors, and instead sought to rely on generalized findings of societal discrimination to justify its affirmative action program. ${ }^{80}$ Returning to the arguments first made by Justice Powell in Bakke, the Court noted that "[t]o accept Richmond's claim that past societal discrimination alone can serve as the basis for rigid racial preferences would be to open the door to competing claims for 'remedial relief' for every disadvantaged group." ${ }^{\text {81 }}$

The Croson case is widely seen as having solidified the Court's proscription on societal discrimination as a justification for race-conscious affirmative action efforts, ${ }^{82}$ yet the Court's opinions were largely devoid of any analysis relating to societal discrimination beyond what had been traversed in earlier cases. Just as important as the Court's proscription on remedying societal discrimination was Justice O'Connor's recognition that the City of Richmond had the power to remedy private

${ }^{79}$ Id. at 505 (plurality opinion), id. at 524-26 (Scalia, J., concurring).

80 Id. at 504.

81 Id. at 505.

82 See, e.g., Ian Ayres \& Frederick E. Vars, When Does Private Discrimination Justify Public Affirmative Action? 98 Colum. L. REV. 1577, 1584 (1998) (noting that after Croson "[i]t is clear that certain forms of "societal discrimination" do not create a sufficient factual predicate" for governmental affirmative action programs); Ruth Bader Ginsburg \& Deborah Jones Merritt, Affirmative Action: An International Human Rights Dialogue, 21 CARDozo L. Rev. 253, 267 (1999) ("State and local attempts to remedy "societal discrimination" have not survived Court scrutiny" after Croson."); Paul Mishkin, Foreword: The Making of a Turning Point-Metro and Adarand, 84 CALIF. L. REV. 875, 877 (1996) (noting that a majority in Croson reaffirmed "Wygant's rejection of societal discrimination as a basis for state affirmative action."); Girardeau A. Spann, Affirmative Action and Discrimination, 39 How . L.J. 1, 28 (1995) (Croson held that a desire to remedy societal discrimination will not meet the Court's strict scrutiny). 
discrimination through its spending power so long as it did so in a manner that was consistent with equal protection mandates. Writing for three members of the Court, Justice O'Connor noted in her plurality opinion that, "As a matter of state law, the City of Richmond has legislative authority over its procurement policies, and can use its spending powers to remedy private discrimination, if it identifies that discrimination with the particularity required by the Fourteenth Amendment. ${ }^{93}$ The three dissenting Justices likewise agreed that the city had a compelling interest in ensuring that its funds were not used to further discrimination or its effects, though the dissenters chided the plurality for derisively labeling the discrimination that had affected the contracting industry as "mere "societal discrimination" rather than as established evidence of past discrimination. ${ }^{84}$ Justice O'Connor - as is typical of her race discrimination opinions ${ }^{85}$ - failed to articulate what the requisite particularity might be, or under what circumstances she might be willing to uphold race conscious efforts instituted through the government's spending power, choosing instead to leave the issue unresolved and unexplored. ${ }^{86}$
83 Id. at 492.
${ }^{84} I d$. at 541.

85 Justice O'Connor has made it a judicial habit to theoretically leave the door open on race conscious governmental efforts, though she has yet to find a race conscious plan that she found was consistent with the Equal Protection clause. This is particularly true of her voting rights decisions where, while joining the Court to invalidate race-conscious districts, she repeatedly claims that it is possible that she would vote to uphold a district under proper circumstances. See Miller v. Johnson, 515 U.S. 900, 928-29 (1995) (O’Connor, J., concurring) (“Application of the Court's standard does not throw into doubt the vast majority of the Nation's 435 congressional districts . . . even though race may well have been considered in the redistricting process.”); Bush v. Vera, 517 U.S. 952, 977 (1996) (O'Connor, J., concurring) (while invalidating Texas District noted that "compliance with the results test [of section 2] ... can be a compelling state interest").

${ }^{86}$ For an excellent attempt to give meaning to Justice O'Connor's suggestion see Ian Ayres \& Frederick E. Vars, When Does Private Discrimination Justify Public Affirmative Action? 98 Colum. L. Rev. 1577 (1998). 
The Court's struggle to define the contours of permissible government actions continued in the following Term when the Supreme Court applied an intermediate level of scrutiny to uphold a federal preference program that was similar in many respects to the program reviewed in Croson. ${ }^{87}$ The program at issue in Metro Broadcasting, Inc. v. FCC provided preferences in distributing broadcast licenses intended to encourage and enhance minority participation in the broadcasting industry. ${ }^{88}$ Rather than relying on societal discrimination to justify the need for racial preferences, the program's rationale turned on a controversial argument that promoting minority ownership would likewise promote a diversity of views on the airwaves, which the FCC had determined was seriously lacking in many markets. ${ }^{89}$ In one of his last opinions for the Court, Justice Brennan applied an intermediate level of review to conclude that increasing broadcast diversity was an important governmental objective and that the program was designed to reasonably serve that interest. ${ }^{90}$

Although the Court did not discuss societal discrimination in Metro Broadcasting, the case will ultimately prove important for my argument because the majority's opinion rested in significant part on a constitutional concern that is analogous to a principle that animates the government's spending

87 See Metro Broadcasting, Inc. v. FCC, 497 U.S. 547 (1990).

${ }^{88}$ Id. at 560.

${ }^{89}$ Without mentioning the term societal discrimination, the Court did note that the "effects of past inequities stemming from racial and ethnic discrimination have resulted in a severe underrepresentation of minorities in the media of mass communications." Id. at 566 (quoting H.R. Conf. Rep. No. 97-765, p. 43 (1982)).

90 Metro Broadcasting, 497 U.S. at 600-01. An aspect of the FCC policy that is often overlooked by its critics is that the program was based on extensive legislative findings that documented the link between minority ownership and a diversity of views. As Justice Brennan noted, “The FCC's conclusion that there is an empirical nexus between minority ownership and broadcasting diversity is a product of its expertise, and we accord its judgment deference." Id. at 570. 
powers. One reason the Court upheld the broadcasting licenses' preference program is that it has long treated the airwaves as involving a limited public resource that is regulated by the government in the pursuit of the public interest. ${ }^{91}$ Relying on its past precedent, the Court noted that "[s]afeguarding the public's right to receive a diversity of views ... is therefore an integral component of the FCC's mission," and this recognition of the government's power to pursue its own vision of furthering racial justice may prove essential in the application of the government funding cases to remedying societal discrimination. ${ }^{92}$

Nevertheless, the Court's decision in Metro Broadcasting had an unusually short shelf life. Following significant changes in Court personnel, the Supreme Court reversed itself five years later by holding that all governmental racial classifications, federal and state alike, are subject to the Court's strict scrutiny. ${ }^{93}$ Importantly, the Court did not alter the essential conclusion of the Metro Broadcasting decision that certain objectives might be upheld under an intermediate or rational level of scrutiny that would not survive the Court's strict review, at least as a theoretical matter. ${ }^{94}$ Indeed, this

91 See Red Lion Broadcasting Co. v. FCC, 395 U.S. 367, 390 (1969) (quoted in Metro Broadcasting at 566-67).

92 Justice O'Connor's dissenting opinion stressed that the FCC program had not been enacted pursuant to the government's section 5 powers to enforce the Fourteenth Amendment, and specifically left open the nature of Congress' "considerable lattitude" to use its section 5 powers. See id. at 60506 (O'Connor, J., dissenting). The dissent likewise reiterated its rejection of societal discrimination as a compelling governmental interest. See id. at 613-14.

93 See Adarand Constructors, Inc. v. Pena, 515 U.S. 200 (1995). By the time of the Court's decision in Adarand, Justices Souter, Thomas, Ginsburg and Breyer had joined the Court, replacing Justices Brennan, Marshall, Blackmun and White.

94 See Charles Fried, Comment, Metro Broadcasting, Inc. v. FCC: Two Concepts of Equality, 104 HARV. L. REV. 107 (1990) (criticizing Metro Broadcasting for using intermediate level of scrutiny). 
conclusion flows naturally from the Court's decision in Adarand, which plainly suggested that the level of review might often prove critical to whether the program would be upheld, otherwise the dispute over the appropriate standard would have been meaningless. The Court also left open the possibility that it might uphold governmental efforts designed to remedy private discrimination when it referred to the "unhappy persistence of both the practice and the lingering effects of racial discrimination," noting that "the government is not disqualified from acting in response to it." 95

This review of the Court's doctrine offers several important insights relating to the government's power to remedy societal discrimination. Perhaps most important, it seems beyond question that this is one area where the Court's level of scrutiny has proved determinative in nearly all of the cases reviewed. ${ }^{96}$ Although the Court has equivocated on the proper standard to apply in reviewing federal programs, it has plainly held that programs designed to remedy societal discrimination cannot satisfy the Court's strict scrutiny, although the programs may be upheld under a lower level of review. I will later argue that when governmental remedial efforts are tied to a spending power, federal or local, they are properly analyzed under a form of rational basis review and should be upheld so long as the programs are not structured in a manner that relies on racial quotas. ${ }^{97}$ It is also clear that the Supreme

95515 U.S. at 237. See also Ayres supra note 87 (discussing ways in which government can redress private discrimination).

${ }^{96}$ Lower courts have upheld gender-related affirmative action programs under an intermediate level of scrutiny, while invalidating the race specific aspects of a program. See Engineering Contractors Ass'n v. Metropolitan Dade County, 122 F.3d 895, 904 n.2 (11 ${ }^{\text {th }}$ Cir. 1997) ("[I]t is clear to us that a gender-conscious affirmative action program can rest safely on something less than the 'strong basis in evidence' required to bear the weight of a race-or-ethnicity-conscious program.”).

97 See section IV.A infra. 
Court has never defined the concept of societal discrimination, even though having a proper definition would help explicate what the programs are actually intended to remedy.

Despite the lack of a definition, it is possible to discern the Court's concerns regarding remedying societal discrimination, all of which were originally articulated by Justice Powell is his Bakke opinion. When it comes to remedying societal discrimination, the Court is troubled by the possibility that allowing race-based remedies would lead to a slippery remedial slope where a program might be based on at best attenuated discrimination, and may just as likely be the result of political preferences. In addition, there is a critical subtext to the Court's decisions, alluded to by Justice Powell in Wygant, ${ }^{98}$ namely that given the pervasive influence of societal discrimination, allowing governments to remedy societal discrimination would entail too much affirmative action - would entail too much redistributing of existing resources. This is a concern the Court has expressed on a number of occasions, and one that has shaped its Equal Protection doctrine, including as it relates to remedying societal discrimination. ${ }^{99}$

\section{Societal Discrimination and Disparate Impact Theory.}

The concept of societal discrimination has undeniably had its greatest direct influence in the Court's affirmative action jurisprudence, but it also fully permeates the Court's antidiscrimination doctrine although often in subtle forms. In its redistricting cases, for example, the Court has acknowledged the role societal discrimination has played in producing polarized voting patterns, which

98 See Wygant, 476 U.S. at 278 n.5, and text accompanying note 63, supra.

99 See, e.g., Washington v. Davis, 426 U.S. 229, 248 (1976) (noting that permitting a constitutional disparate impact challenge would have required intervening in many aspects of the status quo); see also Michael Selmi, Proving Intentional Discrimination: The Reality of Supreme Court Rhetoric, 86 GEO. L.J. 280, at 322-23 (1997) (discussing cases where the Court has shied away from challenges that would "invalidat[e] an extensive array of social services."). 
in turn have often necessitated drawing district lines that provide minority voters with the statutorily required opportunity to elect candidates of their choice consistent with the dictates of the Voting Rights Act. ${ }^{100}$ As was true in the affirmative action context, which the redistricting cases closely parallel,,${ }^{101}$ the Court has considered the argument relating to societal discrimination as an inadequate basis through which to justify taking race into account in drawing district lines. ${ }^{102}$ The Court has also recognized the role societal discrimination has played in producing, and preserving, segregated school districts, though increasingly the Court sees such results as the product of private preferences disassociated from discrimination. ${ }^{103}$

In the voting rights and education contexts the concept of societal discrimination has admittedly played a relatively minor role. In contrast, the idea has played a strong supporting role, although always implicitly, in the development of the disparate impact theory as applied to employment discrimination. The Court first recognized the disparate impact theory in the Title VII case Griggs v. Duke Power Co., when it held that an employer may be required to take action to remedy the disparate effects of its employment practices even when those effects are not the product of intentional

100 See Shaw v. Hunt, 517 U.S. 899 (1996); Johnson v. DeGrandy, 512 U.S. 997 (1994).

101 See Selmi, supra note 99, 317 (arguing that "the redistricting cases are ... akin to affirmative action cases").

102 See Miller v. Johnson, 515 U.S. 900 (1995) (invalidating Georgia congressional redistricting); Shaw v. Hunt, 517 U.S. 899 (1996) (invalidating North Carolina congressional district).

103 This sentiment is particularly prevalent in the Court's recent education cases. See Missouri v. Jenkins, 515 U.S. 70 (1995); Freeman v. Pitts, 503 U.S. 467 (1992); Board of Education v. Dowell, 498 U.S. 237 (1991). 
discrimination. ${ }^{104}$ At issue in the Griggs case was a requirement that workers possess a high school degree and pass two written examinations in order to be assigned outside of the labor department. ${ }^{105}$ As a result of the schooling system in North Carolina, where the case arose, far more whites than blacks had high school degrees, and whites also performed substantially better on the written examinations. ${ }^{106}$ In approving the disparate impact theory as a valid interpretation of Title VII, the Court explained, "Because they are Negroes, petitioners have long received inferior education in segregated schools ...."107

As should be clear, this is nothing other than a recognition of the role societal discrimination had played in producing a discriminatory education system that carried over into the workplace. There was no allegation, after all, that the company had in any way contributed to the discriminatory education system, and yet to ensure that tests did not serve as an "artificial, arbitrary, and unnecessary barrier[] to employment" the Court required that an employer establish that the disputed practice "bear a demonstrable relationship to successful performance of the jobs for which it is used."108 What the Court left unanswered, is why a private employer should be obligated to take steps to remedy the effects of governmentally supported and imposed segregation, particularly when the Court

104401 U.S. 424 (1971).

105 Id. at 427-28. The test requirements were imposed the day after Title VII became effective and likely could have been challenged under a theory of intentional discrimination. See id. at 427.

106 Id. at 428 .

107 Id. at 430 .

108 Id. at 431. The test, with some modifications, has now been codified as part of Title VII. See 42 U.S.C. $\S 2000 \mathrm{e}-2(\mathrm{k})(1)(\mathrm{A})$. 
has largely forbidden governments from taking such action. Indeed, one of the many ironies in the Court's antidiscrimination jurisprudence is that only private entities can remedy what is a social problem. Part of the reason for this strange turn of events is that neither the Court nor commentators has paused to define societal discrimination, or explore its important implications, an issue to which I will now turn.

\section{B. Defining Societal Discrimination.}

As noted earlier, the Court has never sought to define the term societal discrimination, other than to suggest that it is discrimination that is not traceable to a particular actor. ${ }^{109}$ Equally important, in none of its cases has the Supreme Court sought to understand the cause of the statistical disparities that prompted the various remedial efforts challenged in the affirmative action cases. Understanding the origins of societal discrimination requires asking how the present conditions arose. How, for example, did more than $99 \%$ of city construction dollars go to white contractors in the City of Richmond - a city with a majority black population? ${ }^{110}$ Why were there no minorities in the medical school at the University of California at Davis, and why had no women occupied any of the skilled craft positions in the Department of Transportation for Santa Clara County? ${ }^{111}$ Why had there not been a black Congressperson from North Carolina since Reconstruction, a state in which the population is

109 See supra section II.A.

110 See City of Richmond v. Croson, 488 U.S. 469 (1989).

111 Johnson v. Santa Clara County Trans. Ag'y, 480 U.S. 616 (1987). For an interesting and extensive discussion of the case, and its origins, see UROFSKY, supra note 66. 
approximately one-third African American? ${ }^{112}$

Although addressing these questions would appear essential to resolving the claims raised in each of the cases, there has been little interest either, on the Court or among the parties, in exploring the underlying causes of the racially disparate conditions. Part of the reason for the parties' reluctance has to do with the background assumptions that inform and govern the legal analysis. To many, the reason for the disparate results is all too obvious: the explanation is discrimination, and in most cases it is intentional discrimination. ${ }^{113}$ While this assumption is well grounded factually, particularly given that many of the cases discussed above began in the 1970s, to others, including a majority of the Justices on the Supreme Court, the issues are not nearly so clear cut. In fact, their thinking appears defined by a contrary presumption, namely that private preferences, as well as justifiable reliance on different skills that are the product of legitimate factors, are primarily responsible for the observed results. ${ }^{114}$ Justice O'Connor best represents this viewpoint, noting on a number of occasions that there is no reason to expect African Americans and whites to "choose a particular trade

112 See Shaw v. Reno, 509 U.S. 630 (1993). The North Carolina redistricting has now produced an extensive record intended to justify the need for including race as a factor.For an extended discussion of the process in North Carolina see J. Morgan Kousser, Colorblind InJustice 243276 (1999).

113 This issue was framed perhaps most clearly by the Department of Justice in its Bakke brief, where the government sought to explain the Executive Order program that required federal contractors to take affirmative action in the following way: "The Executive Order program requires federal contractors to take affirmative action to prevent disproportionately low employment of women and minorities in their work forces, starting from the assumption that most disproportionately low employment is the result of discrimination if not of the contractor involved, than of someone else." Brief of the Department of Justice, supra note 23, at 33-34 (footnote omitted).

114 See Selmi, supra note 99, at 282-83 
in lockstep proportion to their representation in the local population." 115 As a result, the Supreme Court has required a strong record of identified discrimination before it will allow governmental entities to engage in affirmative remedial efforts.

In many ways, this proposition is unremarkable — requiring proof of discrimination is generally consistent with the burdens in civil cases. The difficulty arises, however, not from the requirement of proof but from what the Court accepts as proof of discrimination, in particular from the Court's unwillingness to accept stark racial or gender disparities, combined with a background history of discrimination, as sufficient to establish a predicate that would allow the government to take affirmative remedial measures. ${ }^{116}$ Instead, the Court labels these situations as involving societal discrimination for which no one appears responsible, and thus no one can seek to remedy.

Requiring identified proof of discrimination also creates a practical difficulty for governments interested in correcting the effects of societal discrimination. Speaking of Santa Clara County's difficulty in defending its promotion decision in the Johnson case, Melvin Urofsky aptly characterizes the dilemma as compelling the County to decide "how to defend a program based on an

115 City of Richmond v. J.A. Croson Co., 488 U.S. 469, 507 (1989); see also Sheet Metal Workers v. EEOC, 478 U.S. 421, 494 (1986) (O’Connor, J., concurring in part and dissenting in part) ("[I]t is completely unrealistic to assume that individuals of one race will gravitate with mathematical exactitude to each employer or union absent unlawful discrimination.”). As I have previously written, I believe Justice O'Connor's perspective has the issue exactly backwards. Without some explanation, we should expect whites and African Americans to pursue careers with roughly the same interests. See Selmi, supra note 99, at 283.

116 See Selmi, supra note, at 334-50 (discussing limitations of the Court's doctrine). 
assumption of prior bias without admitting the County had, in fact, discriminated against women."117

The easiest way for a political actor to resolve this dilemma is to attribute the disparities to societal

discrimination without any further discussion. But without defining what is meant by societal

discrimination, the Court has effectively precluded this move, and at the same time, largely limited the efficacy of governmental efforts to redress racial inequities. There are, however, two distinct concepts of societal discrimination, and delineating them will help justify the government's duty to take remedial action.

\section{Discrimination in the Air.}

Based on the Supreme Court's analysis, its common working definition of societal discrimination is also the most obtuse or unhelpful. The Court sees societal discrimination as anything that is not identifiably, or lawfully, attributable to the particular defendant, ${ }^{118}$ what amounts to a form of

117 UROFSKY, supra note 66, at 83 (footnote omitted). The Supreme Court has likewise recognized the difficulty in requiring governments to document their own discrimination. See Johnson, 480 U.S. 616, 633 (1987) ("A corporation concerned with maximizing return on investment ... is hardly likely to adopt a [n affirmative action] plan if in order to do so it must compile evidence that could be used to subject it to a colorable Title VII suit."); Wygant, 476 U.S. at 290 (O'Connor, J., concurring) (requiring findings of past discrimination would undermine efforts at ensuring voluntary compliance with antidiscrimination law) In the case of Diane Joyce, there was substantial evidence of discrimination. The dispatcher office in which she sought work was described as an old boy network "impenetrable to outsiders," and in 1974 Diane Joyce's first effort to take the road dispatcher test was rebuffed because she lacked road crew experience. That same year Mark Johnson was allowed to take the test despite his lack of experience, and it was this experience as a road dispatcher, discriminatorily denied to Joyce, that he later relied on to argue that he was better qualified for the position that ultimately went to Joyce. See UrOFSKY, supra note, at 7-12.

118 See supra text accompanying notes 26-30, 62-64. By using the term "lawfully," I mean to refer to the Court's disparate impact cases where it has never used the term societal discrimination; as a result, it seems fair to suggest that the Court does not believe such cases raise questions relating to societal discrimination, but instead involve a form of discrimination that is at least statutorily chargeable to the particular defendant even if the defendant had little, or nothing, to do with creating the underlying 
"discrimination in the air" because it is not tied to any particular culpable party. As an analytical concept, discrimination in the air proves rather empty for it consciously avoids addressing the origins of discrimination to determine who ought to be held accountable. When used in this common fashion, societal discrimination is little more than a legal conclusion, one that means discrimination for which no one is legally responsible.

\section{Societal Discrimination as Cumulative Acts.}

A better approach would aim to unpack the nature of societal discrimination, to identify the varied acts that have produced what we can identify as a discriminatory condition that does not have an obvious or direct causal actor. One way to understand this meaning of societal discrimination is to see it as the product of cumulative acts, none of which may suffice as the primary or sole cause but all of which contribute to producing unequal results or conditions that are racially biased. ${ }^{119}$ These practices will likely have both public and private aspects, and some may even be so intertwined as not to be easily severable into public or private components ultimately frustrating the causal inquiry the courts have imposed.

This difficulty illustrates an important limitation on the Court's discrimination doctrine $-\mathrm{a}$ doctrine that is not tailored to addressing discrimination that has public and private components. Although the Court has on various occasions crafted rules to accommodate discrimination with multiple

conditions that have contributed to the results in question.

119 For an excellent discussion of how cumulative social effects can have a forceful impact on perpetrating gender discrimination see Virginia Valian, Why So Slow? The Advancement of WOMEN (1998). 
causes,${ }^{120}$ it has never seen fit to derive an analytical construct for discrimination that is the product of what might be defined as a public- private partnership, but instead typically defines such discrimination as beyond judicial reach.

Consider the case of contract set-asides, which are intended to provide opportunities for minority contractors based on the assumption, and sometimes the proof, that minorities have not been afforded adequate access to the contracting industry. ${ }^{121}$ As noted earlier, the critical question underlying the programs is why have so few minority contractors shared so little in public contracting programs, at least in those cities that have felt a need to adopt set-aside programs. In Richmond, Virginia, the site of the Supreme Court's Croson decision, minority contractors obtained less than one percent of city contracts despite constituting more than half of the city population. ${ }^{122}$ Although the numbers were stark and on their own appeared quite probative, it was not so easy to identify the cause of the contract disparities. No evidence was adduced in the case to suggest that minorities were not

120 See Price Waterhouse v. Hopkins, 490 U.S. 228 (1989) (mixed-motive cases in employment discrimination); Mt. Healthy City Sch. Dist. v. Doyle, 429 U.S. 274 (1977) (mixed motive case in First Amendment context).

121 For an interesting exploration of the contract set-aside provision in Richmond see W. AvON Drake \& Robert D. Holsworth, AfFirmative Action and the Stalled Quest for Black PROGReSs (1996). For additional discussions of discrimination in the contracting industry see Hyman Frankel, Opportunity Denied! New York State's Study of Racial and Sexual Discrimination Related to Government Contracting, 26 URB. LAw . 413 (1994); Robert E. Suggs, Racial Discrimination in Business Transactions, 42 Hastings L.J. 1257 (1991); Roger Waldinger \& Thomas Bailey, The Continuing Significance of Race: Racial Conflict \& Racial Discrimination in Construction, 19 POL. \& Soc'y 291 (1991).

122 Croson, 488 U.S. at 479 (noting that the "Proponents of the set-aside provision relied on a study which indicated that, while the general population of Richmond was $50 \%$ black, only $0.67 \%$ of the city's prime construction contracts had been awarded to minority businesses in the 5-year period from 1978 to $1983 . ")$ 
sufficiently skilled to perform the work that was being contracted out, nor was there any reason to believe, other than by virtue of their underrepresentation, that minorities were uninterested in the contracting jobs. Yet, it was also difficult to prove that the city, or even a particular contractor, had consciously excluded minorities from the work, at least after the 1970 s or early 80 s, and the case largely turned out how the underrepresentation of minorities in the contracting industry was to be interpreted - either as evidence of a lack of interest or as a sign of discrimination within the industry. Based on what is known about the contracting industry and the skills required for the jobs, the most likely explanation for the disparity in contract allocation was a complicated web of discrimination:

African Americans were not part of the word-of-mouth recruitment process that typically defines the construction business, which often includes many small family businesses. ${ }^{123}$ In some instances, minority contractors were likely discouraged from applying or bidding on jobs and rather than file discrimination complaints they may have simply moved into other occupations that were less openly hostile to their participation. City contracts were also passed on by various personal contacts, which may have ultimately produced a discriminatory distribution system that would be difficult to prove under the intent standard the Court requires for constitutional claims. ${ }^{124}$

African Americans were also likely at a capital disadvantage in opening their own businesses to compete directly for city contracts, a disadvantage that almost certainly can be partly

123 DraKe \& HolsworTh, supra note 121, at 84 (describing the contacts and networking necessary in the construction business).

124 See Adarand Construc. v. Slater, 228 F.3d 1147, 1171 (10 ${ }^{\text {th }}$ Cir. 2000) ("The government's evidence strongly supports the thesis that informal, racially exclusionary business networks dominate the subcontracting construction industry, shutting out competition from minority firms."). 
traced to the history of forced segregation that had a long life in Richmond. ${ }^{125}$ Indeed, it would not take much imagination, or documentation, to establish that the government played some significant role in limiting access to the contracting business and perpetuating a system that awarded contracts overwhelmingly to white contractors, and it seems equally clear that the government should have some responsibility for remedying these persistent inequities. ${ }^{126}$

As an analytical matter, this line of reasoning may appear problematic in that it has the trappings of a disparate impact claim, which the Court has definitively held is not encompassed by the Equal Protection clause. ${ }^{127}$ From this perspective, the argument might be that the government has not directly caused any substantial degree of discrimination, but instead enters a contracting market in which

125 See The Compelling Interest for Affirmative Action in Federal Procurement, 61 FED. REg. 26058 (1996) (detailing discrimination in capital markets). See generally Melvin L. Oliver \& Thomas M. Shapiro, Black Wealth/White Wealth: A New Perspective on Racial INEQUALITY (1995) (describing disparity in wealth between blacks and whites).

126 The notion that the government had an obligation to undo the past practices provided the underlying rationale for the adoption of construction goals in Richmond. See DRAKE AND HoLSWORTH, supra note 121, at 68-71. The economic set-aside programs arose after a black majority was elected to the City Council and were part of a larger effort to help "shape economic development policy to benefit of African Americans" after years of neglect. See id. at 71. The program adopted in Richmond was roundly criticized by the Supreme Court because, among other things, it included Alaskan Aleuts among the groups that were eligible to participate in the program, and sought to ensure that at least $30 \%$ of the city's construction funds went to minority contractors. See Croson, 488 U.S. at 478. Yet, the definition of disadvantaged groups that the city used was taken directly from the federal program that had been upheld by the Supreme Court in Fullilove, and the $30 \%$ figure was chosen because it represented the midway point between the percentage of contracts that currently were distributed to minority contractors and the percent of the population that was African American. See DraKe \& Holsworth, supra note 121, at 82. The plan was also adopted after the completion of a study on minority participation in the construction industry.

127 See Washington v. Davis, 426 U.S. 229 (1976). Even as a disparate impact claim, the issue would be a difficult one unless a specific practice could be identified as causing the discriminatory results. See 42 U.S.C. $\S 2000 \mathrm{e}-2(\mathrm{k})(1)(\mathrm{B})$. 
African Americans have clearly been disadvantaged by the effects of private practices rather than the intentional acts of the government. It is my own sense that this analogy is mistaken - there was nothing neutral or inadvertent about the discrimination that was inflicted upon African Americans in the contracting business or elsewhere; rather, the cases raise proof problems within the Court's intentional discrimination framework, given that it is difficult to establish the direct causal link the Court requires because of the multiple causes and actors that are involved, some of which may extend far into the past, too far for the Court's own sense of remedial justice. ${ }^{128}$ Even if the conditions are seen as resting on a disparate impact theory, I will explain in part IV how the government can use its spending power to alleviate practices that have a disparate effect so that accepting the argument that societal discrimination stems from unintentional discrimination should not stand as a barrier to the government's remedial efforts. $^{129}$

The world of contracting is hardly an isolated example of the government's role in creating and perpetuating societal discrimination, and similar stories can be told in the context of both the voting and education, though the analysis becomes somewhat more complicated outside of the commercial realm of contracting because voting, education and housing all involve what courts often see

128 Justice Scalia has been most forthright in stating such a position. He has written: "At some time, we must acknowledge that it has become absurd to assume, without any further proof, that violations of the Constitution dating from the days when Lyndon Johnson was President, or earlier, continue to have an appreciable effect upon current operation of schools." Freeman v. Pitts, 503 U.S. 467, 503 (1992) (Scalia, J., concurring). With respect to disparate impact claims brought under Title VII, George Rutherglen has incisively suggested that we should view such claims as intentional discrimination claims where the prime perpetrator is simply too difficult to identify. See George Rutherglen, Disparate Impact Under Title VII: An Objective Theory of Discrimination, 73 VA. L. REV. 1297 (1987).

129 See infra section IV. 
as private preferences of individuals that are not easily subject to government regulation. With respect to voting, it is easily overlooked in the redistricting cases that the need to include race as an explicit factor in drawing districts arises from the reality that white voters rarely vote for African-American candidates. ${ }^{130}$ Some of this unwillingness has to do with governmentally imposed voting restrictions on African Americans, which have direct and indirect effects that yet to recede. ${ }^{131}$ But some of the animus stems from private biases, simple prejudice, that while influenced by governmental action is more clearly attributable to personal beliefs that are often thought to be beyond the reach of the law. Additional factors that do not directly implicate race include the advantage incumbents have in elections, as well as financial advantages whites tend to have due to their own wealth and in their ability to attract funds. ${ }^{132}$ Although the government would seemingly have a strong and constitutionally permissible incentive to eradicate discriminatory private beliefs, ${ }^{133}$ the Court has been reluctant to consider racial redistricting as

130 The phenomenon of racial bloc voting has been well-documented. See generally QuIET Revolution in the South: The Impact of the Voting Rights Act, 1965-1990 (Chandler Davidson \& Bernard Grofman, eds., 1994). In North Carolina, in 1982 and 1984, more than $90 \%$ of African-Americans voted for the African-American candidate in the two races where they had the opportunity to do so, while 86 to $88 \%$ of the whites voted for a white candidate. See Krousser, supra note 112, at 273 . In addition to racial bloc voting, lower voter turnouts and registration among African Americans contributes to the difficulties black candidates have had getting elected, as does the power of incumbency. See id. at 259-60 (discussing North Carolina elections).

131 See, e.g., Roy L. Brooks, Integration or Separation? A Strategy of Racial EQuAlity 88-92 (1996). Pamela Karlan and Daryl Levinson have suggested that the role the state has played in "creating and perpetuating" racial bloc voting should take these cases out of the realm of non-remedial societal discrimination. See Pamela S. Karlan \& Daryl J. Levinson, The Importance of Political Deliberation and Race-Conscious Redistricting: Why Voting is Different, 84 CALIF. L. REv. 1201, 1232 n.153 (1996).

${ }^{132}$ KROUSSER, supra note 112, at 258.

133 See, e.g., Palmore v. Sidoti, 466 U.S. 429 (1984). The government can surely seek to change even these private discriminatory beliefs, and has undertaken over the years frequent if 
an acceptable means of achieving that permissible goal. ${ }^{134}$

Education likewise provides a complicated web of motives and causal inquiries. No one would deny the government's responsibility for establishing and maintaining segregated schools, as well as the many and diverse efforts school districts employed to avoid desegregation mandates. ${ }^{135}$ But it is more difficult to assess responsibility for the failure to achieve any degree of desegregation since the early 1970s, and much of that failure must lie at the feet of those who so strongly resisted integrating schools, including many public officials. ${ }^{136}$ This is not to suggest that governments do not share in the responsibility; indeed, the primary difficulty in the desegregation cases, particularly those that are still being litigated, is deciding who should bear the responsibility for the fact that so many schools remain segregated. ${ }^{137}$ In an insightful dissenting opinion in a school desegregation case, Justice Souter ineffective efforts, such as President Clinton's race initiative, which no one would contend was unconstitutional.

134 See Melissa L. Saunders, Reconsidering Shaw: The Miranda Race-Conscious Districting, 109 YALE L.J. 1603 (2000).

135 See, e.g., Green v. County School Board of New Kent County, Virginia, 391 U.S. 430 (1968) (invalidating freedom-of-choice plan); Griffin v. County School Board of Prince Edward County, 377 U.S. 218 (1964) (finding that closing of the public schools conflicted with the Court's mandate in Brown).

136 See James T. Patterson, Brown v. Board of Education: A Civil Rights Milestone And its Troubled Legacy 115-17 (2001) (discussing important role public officials' resistance to desegregation played)

137 For a discussion of the current state of desegregation in public schools see GARY ORFIELD \& Susan E. Eaton, Dismantling Desegregation: The Quiet Reversal of Brown v. Board of EduCATION 1-22 (1996). In an important recent case, the Connecticut Supreme Court found that the state had played a significant role in the present segregation of Hartford's schools even though separate schools had not been part of state policy for nearly a hundred years. The Court found that the state had contributed to the current racial make-up of the schools through the use of standardized tests, school attendance and graduation requirements, the use of financial aid and other means. See Sheff v. O'Neill, 
wondered aloud how it was possible to know, or to determine, whether it was official segregation or the efforts to eliminate segregation that had caused the severe racial imbalance that defines many urban schools today. ${ }^{138}$ It is unquestionably difficult to answer this query, but the problem that has arisen from the Court's doctrine is that it has never asked the question let alone tried to answer it.

Housing offers a similar though surprisingly less well known story. We often treat housing as reflecting core private beliefs, as it is often thought that there is something sacred about allowing individuals to choose where they want to live. ${ }^{139}$ But the government has long been actively involved in shaping those choices and has often done so in discriminatory ways. Following World War II, government efforts to assist in expanding home ownership included explicit directives to avoid lending to racially diverse areas. ${ }^{140}$ Through a series of lawsuits, the government has now acknowledged the discriminatory patterns in which it built public housing, ensuring, through its action,

238 Conn. 1, 11, 678 A.2d 1267, 1274 (1996).

138 See Missouri v. Jenkins, 515 U.S. 70, 164 (1995) (Souter, J., dissenting).

139 This sentiment is reflected in many of the Court's more recent desegregation cases, as expressed most clearly by Justice Thomas who has noted: "The continuing 'racial isolation' of schools after de jure segregation has ended may well reflect voluntary housing choices or other private decisions." Missouri v. Jenkins, 515 U.S. 70, 84 (1995) (Thomas, J., concurring). See also Freeman v. Pitts, 503 U.S. , 495 (1991) (noting that demographics changes are often "the real source of racial imbalance" and "it is beyond authority and beyond the practical ability of the federal courts to try to counteract.”); Dowell v. Bd. of Education, 778 F. Supp. 1144, 1167-71 (W.D. Okla. 1991) (on remand from Supreme Court finding that "[c]urrent residential segregation in Oklahoma City today is caused by the private choices of blacks and whites ...").

140 See Kenneth T. Jackson, Crabgrass Frontier:The Suburbanization of the UNITED STATES 208 (1995). For a recent discussion of the ways in which the government contributed to segregated housing, particularly in Boston, see Michelle Adams, The Last Wave of Affirmative Action, 1998 Wisc. L. REV. 1418-24. 
that public housing perpetuated segregated housing patterns rather than worked to alleviate them. ${ }^{141}$

The government also helped shape housing choices by subsidizing the building of highways to the

suburbs rather than enhancing mass transit systems within the cities, by permitting and often encouraging

zoning laws that made it difficult for lower income individuals to purchase or rent housing in the suburbs,

and by providing various tax incentives for companies to relocate to the suburbs. ${ }^{142}$

In this light, we can see that what the Court has labeled as societal discrimination is best

defined as the product of cumulative acts and forces, some of which directly involve the government and

others of which necessarily implicate the government but more indirectly. ${ }^{143}$ Described in this way,

141 See Raso v. Lago, 133 F.3d 11 ( $1^{\text {st }}$ Cir. 1998) (involving Boston's public housing and 1991 consent decree concerning HUD's failure to ensure equal access to public housing for minority residents); Walker v. Mesquite, Texas, 169 F.3d 973 (5 $5^{\text {th }}$ Cir. 1999) (discussing Dallas' discriminatory policy for locating public housing).

142 See Philip A. Klinker \& Rogers M. Smith, The Unsteady March: The Rise and Decline of Racial Equality in America 359 (1999); see also Richard Ford Thompson, The Boundaries of Race: Political Geography in Legal Analysis, 107 HARV.L. Rev. 1841 (1994) (discussing the many ways in which public and private associations contributed to racial segregation).

${ }^{143}$ A third type of discrimination that might be associated with societal discrimination is the cumulative force of practices that are specific to a particular employer, what is sometimes referred to as institutional racism. See Barbara J. Flagg, Was Blind, But Now I See: White Race CONSCIOUSNESS AND THE LAW 26-28 (1998); Ian Haney López, Institutional Racism: Judicial Conduct and a New Theory of Racial Discrimination, 109 YALE L.J. 1717 (2000). Within this perspective, an employer or entity's practices are tinged with biases in a variety of ways even though no particular practice may be responsible in a legal sense for the discriminatory results. An employer, for example, might use word-of-mouth recruiting, which will then be compounded by subtle biases in the workplace, the combination of which will lead to sharply fewer opportunities for minorities within the organization. Lopez discusses the judicial appointment of grand jurors in Los Angeles county during the 1960s and 70s when the judges tended to appoint people with whom they were personally acquainted, and which, not surprisingly, produced very few minority grand jurors. See Lopez, supra, at 1732-43. In contrast to the first two types of discrimination I have discussed, this form of discrimination primarily involves proof problems and I believe is not properly classified as societal discrimination. Indeed, in employment discrimination, Title VII specifically provides for a proof 
societal discrimination is clearly a social ill that the government should be able to take steps to eliminate or reduce. Indeed, not only should the government be permitted to remedy societal discrimination, but it should be obligated to do so. Societal discrimination serves no positive function; rather, it reduces opportunity for millions of Americans, wastes resources insofar as human talent is not fully developed or used, and foments the bitter racial divide that still defines much of our nation. This is precisely the kind of condition the government should be charged with remedying, and I will suggest in the next two sections that it can do so through its spending power.

\section{The SPEnding Power.}

One way the government can meet its obligation to remedy societal discrimination is through the use of its spending power, which has traditionally afforded the government broad authority to pursue social, economic or political goals through the use of its vast financial power. The federal government has long sought to shape behavior by attaching various conditions to the distribution of its funds on both governmental and individual recipients. ${ }^{144}$ The conditions have ranged widely from seeking to control agricultural production to restricting campaign spending, from requirements that government contractors pay certain wages to their employees to more mundane issues such as

structure to govern circumstances where discriminatory results are the product of employment practices that are "not capable of separation." 42 U.S.C. $\$ 2000 \mathrm{e}-\mathrm{g}$. At the same time, these cases are extremely difficult to prove and may often go unremedied because of the difficulties of proof - but that difficulty alone should not transform the cases into a form of societal discrimination if the concept is to retain any significant meaning.

144 For a comprehensive review of the many cases in which the government has attached conditions to federal spending see Albert J. Rosenthal, Conditional Federal Spending and the Constitution, 39 STAN. L. REV. 1103 (1987). Rosenthal's article was written just before the Court issued a series of important decisions and thus is now better for its historical understanding rather than as an exegisis of existing doctrine. 
promoting sustainable agriculture through the sale of organic coffee in government cafes. ${ }^{145}$ When the government uses its funds to pursue a particular political, social or economic agenda, courts review the programs with considerable judicial deference. ${ }^{146}$ In this section, I will begin to build my argument that the government can use its funds to pursue racial equality in a manner that should survive judicial scrutiny.

The Supreme Court's doctrine relating to government funding decisions is both lengthy and complicated, and involves three discrete but related areas. First, and for the purposes of my argument most important, are a series of cases involving decisions by the government, often involving speech activity, to fund certain activities to the exclusion of others that often are treated under the general rubric of government funding cases. ${ }^{147}$ Second, there are cases implicating what is known as unconstitutional conditions issues where the government conditions a governmental benefit on some

145 See, e.g., United States v. Butler, 297 U.S. 1 (1936) (noting that objectives not within Article I's enumerated powers may be attained through the spending power); Buckley v. Valeo, 424 U.S. 1 (1976) (upholding spending restrictions on candidates who receive federal funds); Harris v. McCrae, 448 U.S. 297 (1980) (upholding federal legislation prohibiting the use of medicaid funds for abortions); Selective Serv. System v. Minnesota Public Interest Research Group, 468 U.S. 841 (1984) (denying federal assistance to students who had not registered for the draft).

146 One commentator has recently suggested that the Supreme Court might be preparing for a shift in the near future at least with respect to conditions imposed on states. See Lynn A. Baker, Conditional Federal Spending After Lopez, 95 Colum. L. REv. 1911 (1995). Professor Baker has suggested that the Court might try to reconcile its permissive stance toward government spending with the Court's far more restrictive view on the ability of the federal government to dictate terms on states that interfere with traditional state autonomy. Since the publication of Professor Baker's article, the Supreme Court has issued a series of decisions holding that individuals cannot sue states for money damages under various federal antidiscrimination statutes, providing some additional support for her argument. See, e.g., Kimel v. Florida Bd. of Regents, 120 S.Ct. 631 (2000) (holding that the ADEA cannot be applied to the states).

147 See infra text accompanying notes 151-211. 
particular behavior, such as complying with a loyalty oath or refraining from political activities while working for the government. ${ }^{148}$ These cases are closely related to the first category, but a separate doctrine has developed around the cases that is often - mistakenly as I will contend - seen as a critical restraint on the government's spending power. Third, the government also uses its funds to provide incentives to induce compliance with other legal provisions, such as prohibiting entities that receive federal funds from engaging in racial discrimination. ${ }^{149}$ In this section, I will concentrate my analysis on the first two categories of cases, and address the third category in the final section of this article.

From the outset, I should note that I will not attempt anything like a comprehensive review of the Court's doctrine but will instead concentrate on a series of cases involving the government's role in various commercial activities, as opposed to situations in which the government places various conditions or restrictions on social welfare benefits, an area that raises an entirely different set of issues. ${ }^{150}$ In particular, I will focus on a spate of decisions the Court has issued in the last decade upholding governmental efforts to fund issues or sides in controversial areas as a way of

148 See infra text accompanying notes 212-27.

149 See 42 U.S.C. § 2000d (Title VI).

${ }^{150}$ For an overview of the benefits cases see Lynn A. Baker, The Prices of Rights: Toward A Positive Theory of Unconstitutional Conditions, 75 CoRNELL L. Rev. 1185 (1990). The literature involving government funding is enormous, especially in the area of the unconstitutional conditions doctrine, which holds a special appeal for constitutional scholars. For a sampling of the principal works see Richard Epstein, The Supreme Court, 1987 Term - Foreword: Unconstitutional Conditions, State Power, and the Limits of Consent, 102 HARv. L. Rev. 4 (1988); Seth Kreimer, Allocational Sanctions: The Problem of Negative Rights in a Positive State, 132 U. PA. L. Rev. 1293 (1984); Kathleen M. Sullivan, Unconstitutional Conditions, 102 HARV. L. Rev. 1415 (1989); William Van Alstyne, The Demise of the Right-Privilege Distinction in Constitutional Law, 81 HARV. L. REV. 1439 (1968). 
pursuing what the government defines as the public good. I will argue that these cases provide the necessary constitutional space for the government to use its spending power to seek to remedy societal discrimination, something the government may only accomplish through indirect means that are tied to federal funding.

\section{A. The Recent Government Funding Cases.}

\section{Rust v. Sullivan.}

As it relates to the goal of remedying societal discrimination, the most important case in this area is Rust v. Sullivan, where the Supreme Court upheld restrictions imposed on health clinics that received federal funding designated for a particular program. ${ }^{151}$ In many ways, Rust was an extension of two earlier Supreme Court cases that upheld state and federal determinations not to use medicaid funds to pay for most abortions. ${ }^{152}$ In upholding the state decision, the Supreme Court specifically acknowledged the state's lattitude to use its funding to pursue permissible political goals, noting that there was "no limitation on the authority of a state to make a value judgment favoring childbirth over abortion, and to implement that judgment by the allocation of public funds." 153 These cases set the tone for the Court's deferential review of government funding cases, in significant part by applying rationality review to the government restrictions. ${ }^{154}$

At issue in Rust were Department of Health and Human Services regulations that limited

151 Rust v. Sullivan, 500 U.S. 173 (1991).

152 See Maher v. Roe, 432 U.S. 464 (1977); Harris v. McCrae, 448 U.S. 297 (1980).

153 Maher, 432 U.S. at 474; see also Harris, 448 U.S. at 324-25.

154 Maher, 432 U.S. at 478-80; Harris, 448 U.S. at 324-27. 
the ability of health providers receiving federal funds through a program known as Title $\mathrm{X}$ to engage in abortion-related activities, including their ability to counsel clients on the availability of abortion services elsewhere. ${ }^{155}$ The Title X program was introduced in the early 1970 s to provide family planning to lowincome women, and the restrictions challenged in Rust were part of the Reagan Administration's efforts to limit the scope of Title X funding to "preventive family planning" by "clarifying that pregnant women must be referred to appropriate prenatal care services." " 156 These restrictions went beyond prohibiting the provision of abortions at the facilities but also prevented employees of the clinics from discussing abortion with their clients, or from referring them to abortion clinics even when their clients specifically requested a referral. ${ }^{157}$

Given that the Supreme Court had twice previously upheld the government's refusal to fund abortion services, the constitutional challenge in Rust centered on the prohibition on any discussion relating to abortion within a Title $\mathrm{X}$ facility. ${ }^{158}$ In their First Amendment challenge, the petitioners, doctors and health clinics, argued that the regulations constituted impermissible viewpoint discrimination because they were intended to suppress dangerous ideas, namely the advocacy of abortion. ${ }^{159}$ That the

155 Rust, 500 U.S. at 179 (“'[A] Title X project may not provide counseling concerning the use of abortion as a method of family planning, or provide a referral for abortion as a method of family planning.’).

156 See Dorothy E. Roberts, Rust v. Sullivan and the Control of Knowledge, 61 GEO. WASH. L. REV. 587, 598-604 (1993) (discussing history of the regulation).

157 Rust, 500 U.S. at 180 ("The Title X project is expressly prohibited from referring a pregnant woman to an abortion provider, even upon specific request.”).

158 In its opinion, the Court rejected two other challenges to the regulations as being inconsistent with the legislation. Id. at 181-90.

159 Id. at 192. 
restrictions encompassed a particular viewpoint seemed beyond question, and under the Court's developed speech doctrine, which is deeply hostile to viewpoint discrimination, the restrictions surely could have been invalidated and plainly would have if the condition had not been attached to government spending. ${ }^{160}$ However, building on its earlier cases restricting abortion funding, the Court rejected the petitioners' challenge, explaining: "The Government can, without violating the Constitution, selectively fund a program to encourage certain activities it believes to be in the public interest ... In so doing, the Government has not discriminated on the basis of viewpoint; it has merely chosen to fund one activity to the exclusion of the other." 161 The Court added that the government was free to choose to advance permissible goals when appropriating public funds, and was under no obligation to fund competing views. For example, the Court noted in what now appears to be a bit of an anachronistic analogy, the government could provide funds dedicated to promoting democracy without appropriating similar funds intended to support communism. ${ }^{162}$

In its opinion, the Court devoted sparse attention to the question of what goals the government might permissibly pursue through the use of its spending power. ${ }^{163}$ In the abortion context,

160 See Texas v. Johnson, 491 U.S. 397, 414 (1989) ("If there is a bedrock principle underyling the First Amendment, it is that the government may not prohibit the expression of an idea simply because society finds the idea itself offensive or disagreeable.").

161 Id. at 193.

162 Id. at 194.

163 Robert Post has argued that the Court is likely to give the government greater leeway when it is operating in what he defines as managerial domains where the "state organizes its resources so as to achieve specified ends", which are often political in nature. See Robert Post, Subsidized Speech, 106 YALE L.J. 151, 163 (1996). Post contrasts the managerial domain with the domain of public discourse where certain neutrality requirements restrict governmental actions to a greater extent than they do in the managerial realm. See id. at 164; see also Robert C. Post, Between Governance and 
this would now likely turn on whether the regulations constituted an undue burden on a woman's ability to exercise her constitutionally protected right to an abortion, a slightly different test than existed at the time Rust was decided. ${ }^{164}$ But given the Court's earlier decisions in the public funding cases, it would be difficult to see how the Title $\mathrm{X}$ regulations might rise to the level of an undue burden, unless perhaps Title X facilities had a monopoly on health services in a particular area. ${ }^{165}$ One example of the kind of restriction that would likely be impermissible would be if the government sought to require clients of Title $\mathrm{X}$ facilities to agree not to have an abortion as a condition for using the facilities, a condition that would clearly rise to a level of an undue burden that should be quickly invalidated. ${ }^{166}$ Nor could the

Management: The History and Theory of the Public Forum, 34 UCLA L. REV. 1713 (1987) (developing his theory on the managerial and public discourse domains). He notes further that "[w]ithin managerial domains . . . ends may be imposed upon persons.” Post, Subsidized Speech, supra, at 163.

164 See Planned Parenthood v. Casey, 505 U.S. 833, 884-85 (1992) (a statute that affects the right to abortion will be invalidated only if it imposes an "undue burden" on women seeking abortions.) The test devised in Casey was, in fact, quite similar to the standard the Court used in its earlier decisions upholding the governments' determination not to provide medicaid funds for abortions. See Harris v. McCrae, 448 U.S. at 315 ("The Hyde Amendment . . places no governmental obstacle in the path of a woman who chooses to terminate her pregnancy.").

165 One scenario, and this is certainly the weakest part of the Court's opinion, is if the restriction on providing information would effectively have limited the information most, or some, of the clinics' patients were likely to receive. That is, if the patients were only likely to receive information about pregnancy options from the clinic, then the regulations may unduly interfere with her rights. This would obviously be a very difficult burden to establish, and was effectively rejected in the abortionfunding cases. In his dissenting opinion in Rust, Justice Blackmun made a slightly different, and I think even less persuasive, argument noting, “Although her physician's words, in fact, are strictly controlled by the Government and wholly unrelated to her particular medical situation, the Title X client will reasonably construe them as professional advice to forgo her right to obtain an abortion." Rust, 500 U.S. at 217 (Blackmun, J., dissenting).

166 See Harris v. McCrae, 448 U.S. at 317 n. 19 (“A substantial constitutional question would arise if Congress had attempted to withhold all medicaid benefits from an otherwise eligible candidate simply because that candidate had exercised her constitutionally protected freedom to terminate 
government apply its restrictions beyond the workplace to prevent clinic employees from advocating abortions or counseling individuals on their free time.

The breadth of the Court's decision in Rust at times recalls Justice Holmes' famous quip that although a police officer "may have a constitutional right to talk politics ... he has no constitutional right to be a policeman." 167 Under this view, because no entity or person is obligated to accept federal funds, there can be no complaint regarding the particular strings that are attached to those funds, a view that has attracted varying degrees of allegiance throughout the Court's history. ${ }^{168}$ Despite the apparent breadth of the decision, the Court identified several potential limitations on the manner in which the government can disburse its funds.

As just noted, and as will be discussed in more detail below, the most significant limitation falls under what is known as the unconstitutional conditions doctrine, where the government seeks to impose conditions that violate an individual's constitutional rights. ${ }^{169}$ Within its First Amendment jurisprudence, the Court will also provide greater scrutiny of the government's efforts to restrict actions that occur in public fora, where the government has a greater obligation to act neutrally than it does when it is simply funding programs that are intended to further the government's political

pregnancy by abortion.'); Sullivan, supra note 150, at 1464 (withholding funds from a woman who had an abortion would be impermissible).

167 McAuliffe v. Mayor of New Bedford, 155 Mass. 216, 220, 29 N.E. 517 (1892).

168 Indeed, Justices Rehnquist and Scalia seem to hold just such a view. See infra text accompanying notes 211-13. For a critical analysis of this position see Van Alstyne, supra note 150.

169 See section III.C infra. 
agenda. ${ }^{170}$ In addition to these two restrictions, the Court also weighs in the balance the existence of other outlets for the prohibited activity. In the case of abortion counseling, it seemed essential to the Court's ruling that the Title $\mathrm{X}$ clinics could establish separate facilities to provide abortion services so long as those facilities were both financially and physically separate from the federally funded clinics. ${ }^{171}$ As long as it was at least theoretically possible that a separate facility could be established to provide the proscribed activities, the Court did not believe the restrictions unreasonably limited the recipient's speech rights since individuals were not entirely precluded from engaging in the protected speech activity. ${ }^{172}$

For my purposes, three aspects of the decision are worth emphasizing. First, the Court did not subject the Title $\mathrm{X}$ regulations to strict scrutiny, but instead applied what is best described as a rational basis review, though the Court never specified the particular standard it was employing. ${ }^{173}$

170 See Rosenberger v. Rector \& Visitors of the University of Virginia, 515 U.S. 819, 829 (1995) (discussing government's obligations in when public forum at issue); Perry Ed. Ass'n v. Perry Local Educators Ass'n, 460 U.S. 37 (1983) (government has higher degree of neutrality in public forum setting).

171 Id. at 196 ("The Title $\mathrm{X}$ grantee can continue to perform abortions, provide abortionrelated services, and engage in abortion advocacy; it is simply required to conduct those activities through programs that are separate and independent from the project that receives Title X funds.').

172 The Court was far less concerned with whether establishing a separate facility was actually feasible or would provide any practical services. Assuming the clinic was established to serve the same women who would benefit from Title $\mathrm{X}$ funds, the women may never find out about the separate facility given that the Title $\mathrm{X}$ clinic was prohibited from referring their clients to an abortion provider. Similarly, the Title X recipient may not have sufficient additional funds to establish a separate clinic. That said, the Court did not appear concerned about whether a separate clinic could actually be established, only whether the restrictions permitted a separate facility.

173 The Court used language that is often equated with rationality review, noting, for example, that the scope of the project was "permissibly restricted" and that the regulations were "a permissible construction". Id. at 199, 203. The Court also relied on its earlier decisions in Maher and Harris, 
Under a rationality review, the only question the Court considers is whether the governmental restriction is reasonably related to the program's goals, a test that is widely acknowledged to be constitutionally undemanding, ${ }^{174}$ If applied to governmental efforts to remedy societal discrimination this standard of review would likely lead to upholding many of the programs, depending on how the particular program was structured. ${ }^{175}$ Second, it is clear from the decision that the government - and this principle should apply to state and local governments as well as the federal government - can engage in regulation indirectly through the use of public funds that it would not be permitted to accomplish directly. Certainly the government could not have prohibited the clinic employees from discussing abortion-related services absent the provision of federal funds, just as the government could not prohibit abortions more generally. Instead, under its spending power, the government can permissibly pursue its objective of ensuring that federal funds are not used to support or encourage abortions. Third, there is nothing to suggest that the decision would, or should, be restricted or limited to the abortion context, even though the case often reads like one of the Court's more recent abortion decisions and was decided by a bare majority led by the Court's most conservative members. Indeed, though Rust has not been widely applied - and the regulations at issue were rescinded shortly after President Clinton took office ${ }^{176}$ - it

both of which applied rationality review. See supra note text accompanying note 154.

174 See, e.g., Harris v. McCrae, 448 U.S. 297, 324-25 (1980) (applying rationality review to uphold regulation prohibiting medicaid funds to be used for abortions); DANIEL A. FARBER, WILLIAM N. Eskridge, Jr., Philip P. Frickey, Constitutional Law : Themes for the Constitution's Third CEnTURy 2294-97 (1993) (noting that the Court usually finds a way to uphold legislation under rationality review).

175 This issue will be discussed in section IV, infra.

176 See Post, supra note 165, at 168 n. 106 (" The regulations were suspended at the direction of President Bill Clinton in 1993.”). 
has been extended to other areas. ${ }^{177}$

It is instructive to compare the Court's deference to the governmental objectives pursued in Rust through the spending power, to that afforded governmental efforts to remedy societal discrimination. Most notably, other than the unconstitutional conditions check, which I will shortly explain does not pose much of a check, the Court provided no meaningful scrutiny to determine whether the program was pursuing a legitimate purpose, or even whether it was reasonably related, let alone narrowly tailored, to the purpose of the underlying statute. Nor did the Court express concern regarding a potential slippery slope in which funds would be used to infringe or interfere with a range of personal freedoms, but instead the Court was content with approving the government's objective despite its likely impact on the choices of the clients of clinics that received the funds. I will return to the implications of the Court's Rust decision for efforts to remedy societal discrimination after discussing several other recent cases where the Court upheld governmental programs designed to pursue certain social objectives through the spending power.

177 In addition to the cases discussed infra see Board of Regents v. Southworth, 529 U.S. 217,229 (2000) (distribution of funds by college); Urofsky v. Gilmore, 216 F.3d 401, 408 n.6 (4 ${ }^{\text {th }}$ Cir. 2000), cert. denied, 121 S.Ct. 759 (2001) (employee speech); Turley v. Police Dep't, 167 F.3d 757, 761 (2d Cir. 1999) (noting that "the government can without violating the Constitution, selectively fund a program to encourage certain activities."); Hassan v. Wright, 45 F.3d 1063, 1069 ( $7^{\text {th }}$ Cir. 1995), cert. denied, 516 U.S. 842 (1995) (citing Rust for the proposition that there is no affirmative right to government aid). Just last week, the Supreme Court issued a decision that distinguished Rust, in invalidating restrictions that had been placed on the litigation activities of the Legal Services Corporation. See Legal Services Corp. v. Velasquez, Nos. 99-603 \& 99-960 (slip opinion February $28,2001)$. The Court found that the restrictions, which precluded litigation challenges to the recently enacted Welfare Reform Act, were inconsistent with the purposes of the statute and significantly interfered with the role of the judiciary in adjudicating the scope and permissibility of the Act. [N.B. I plan to expand a bit on the Velasquez case prior to publication to explain why the Court saw it as raising a different issue from that raised in Rust.] Interestingly, while the Court distinguishes Rust, it never cites its decision in NEA v. Finley, discussed infra. 


\section{The NEA Controversy.}

The principles discussed in Rust were amplified and applied only a few years later in a Supreme Court decision involving Congress's imposition of certain limits on the distribution of funds by the National Endowment for the Arts ("NEA") to ensure that the grants made by the agency would, among other things, respect general standards of decency. ${ }^{178}$ Four artists whose projects were approved by an advisory panel prior to the adoption of the decency clause challenged the regulations after their proposals were subsequently rejected as being inconsistent with standards of decency. The plaintiffs argued that the regulation violated the First Amendment because it sought to exclude particularly controversial projects from eligibility for public funds. ${ }^{179}$

This case was, in some ways, both much easier and more difficult than Rust. When it comes to funding for the arts, the government surely has wide latitude to choose what projects it wants to fund, yet the regulations were undeniably aimed at suppressing controversial forms of speech, which is one of the core evils protected by the First Amendment. ${ }^{180}$ Although the Government has broad discretion to choose what paintings to hang in its museums, or what projects it wants to subsidize, the controversy arose here because it sought to limit its support based on the views expressed by the artists rather than on the artistic merit of the projects, a restriction that might be applied to limit support of art that criticized the government.

${ }^{178}$ See National Endowment for the Arts v. Finley, 524 U.S. 569 (1998).

${ }^{179} I d$. at $577-78$.

180 See Frederick Schauer, Principles, Institutions, and the First Amendment, 112 HARV. L. REv. 84, 104-06 (1998) (discussing role of viewpoint discrimination in Court's analysis). 
In an opinion authored by Justice O'Connor, who was one of the dissenters in Rust, the regulation was upheld for a variety of reasons, but in particular because the Court held that the government was exercising its discretion to choose among permissible ways to expend its funds. ${ }^{181}$ With respect to the subsidy issue, Justice O'Connor explained, “Although the First Amendment certainly has application in the subsidy context, we note that the Government may allocate competitive funding according to criteria that would be impermissible were direct regulation of speech or a criminal penalty at stake. So long as legislation does not infringe on other constitutionally protected rights, Congress has wide latitude to set spending priorities."182 Justice Scalia's concurring opinion would have gone even further by largely exempting funding decisions from judicial scrutiny altogether. Unlike the majority, Justice Scalia, who was joined by Justice Thomas, conceded that the regulation constituted viewpoint discrimination but considered it constitutional nevertheless, observing that "[i]t is the very business of government to favor and disfavor points of view on . . innumerable subjects ..."183 This case was particularly easy for Justice Scalia insofar as, "Those who wish to create indecent and disrespectful art are as unconstrained now as they were before the enactment of this statute .... they are merely deprived of the additional satisfaction of having the bourgeoisie taxed to pay for it."184 Writing only for himself, Justice Souter made a compelling case in dissent that Finley was a more difficult case than the majority's decision suggested. Justice Souter emphasized that unlike

181 Finley, 524 U.S. at 587-88.

$182 I d$. at $587-88$.

183 Id. at 598 .

184 Id. at $595-96$. 
Rust, the Finley case did not involve the government's role as speaker but instead the government was expending funds to support an important public purpose. ${ }^{185}$ In other words, there was no danger that the art supported by NEA grants was likely to be seen as a government art project, which arguably distinguished the situation from that of health clinics at issue in Rust where the Title X money clearly funded a government program. When the government merely funds a portion of a project, viewpoint discrimination becomes more problematic. "After all," he wrote, "the whole point of the proviso was to make sure that works like Serrano's ostensibly blasphemous portrayal of Jesus would not be funded, while a reverent treatment conventionally respectful of Christian sensibilities, would not run afoul of the law. Nothing could be more viewpoint based than that."186

If taken to an extreme, the Court's decision in Finley might be used to support withholding funds from art that was unpatriotic or racist so long as the messages attendant to the works was not one that the government wished to support, and the decision does not suggest what constitutional limits might apply to that determination. But there do appear to be some limits, at least implicitly. For example, it seems quite likely that the Court would invalidate grants that went only to Republican artists, though it might be able to support Republican-inspired art, and it would just as likely invalidate a grant program that sought to direct funds solely to African-American artists, even though the government might be able to withhold funds from racist art or dedicate funds to promoting African-

185 Id. at 611 (Souter, J., dissenting).

${ }^{186} I d$. at 606 (citations omitted). 
American art. ${ }^{187}$ This distinction - in this case one between funding artists and art - will ultimately play an important role in determining how the government can use its funds to pursue the goal of racial equality.

\section{The Rosenberger Case.}

Justice Souter largely staked his claim in Finley on a case that was decided between Rust and Finley, in which the Court struck down the University of Virginia's refusal to distribute funds from student fees to religious groups. ${ }^{188}$ But the Rosenberger case is more about religion than it is about government funding, and it also implicates the Court's doctrine relating to public fora where the government must exercise more care and less discretion in how it distributes its resources. ${ }^{189}$ The program at issue in Rosenberger provided student funds to qualifying student groups but excluded religious - as well as philosophical, political and several other groups - from receiving funds, ostensibly due to a fear that providing the funds would violate the Establishment Clause. ${ }^{190}$ There was no other stated reason for the restriction, ${ }^{191}$ and once the Supreme Court held that the Establishment Clause would not be violated by including religious groups among the various student groups eligible to

187 See Kreimer, supra note 150, at 1338-39, 1374-75 (discussing providing grants based on political affiliation).

188 Rosenberger v. Rector and Visitors of the University of Virginia, 515 U.S. 819 (1995).

189 Id. at 829 (discussing public forum).

190 Id. at 825 .

191 In the Supreme Court, the University largely abandoned its Establishment Clause argument in favor of arguing that it should be able to "control the use of its public funds." Id. at 838. No Justice on the Court appeared to take this move very seriously, and all concentrated on the Establishment Clause argument. 
receive funds there was seemingly no rationale at all for the continued restriction. As a result, the restriction appeared to result from the state university's desire to disfavor religious groups, which amounted to impermissible viewpoint discrimination, one that was plainly inconsistent with the First Amendment's command of governmental neutrality toward religion. ${ }^{192}$

The Court in Rosenberger sought to distinguish Rust by emphasizing the different roles the government played in the two cases. In Rust, the government "used private speakers to transmit specific information pertaining to its own program" whereas the program at issue in Rosenberger simply aimed at facilitating the speech of third parties. ${ }^{193}$ If this language were taken literally, the government's role as speaker would be critical to determining the constitutionality of a government subsidy program, and this distinction arguably should have produced a different result in Finley where the government sought to facilitate the arts but was not acting as a speaker or even as a funding source to convey a particular message, unless the message was seen as "decent" art, however defined. That said, whatever role the government as speaker distinction actually plays in the Court's doctrine, it is not likely to be relevant in the discrimination area where the government can structure its program, and in some instances already has, in support of a particular purpose.

That Rosenberger was primarily about religion rather than government funding was

192 Id. at 832-34 (holding that the statute was impermissibly viewpoint based). In reaching its conclusion, the Supreme Court principally relied on a religion case, Lamb's Chapel v. Center Moriches Union Free Sch. Dist ., 508 U.S. 384 (1993), which struck down an effort to prohibit religious groups from using school facilities that were otherwise open to the community.

193 Id. at 833-34. See also Legal Services Corp. v. Velasquez, Nos. 99-603 \& 99-960 (slip op. at 7) (noting that "the LSC program was designed to facilitate private speech, not to promote a governmental message."). 
confirmed in a case decided last Term where the government upheld the University of Wisconsin's mandatory fee program over the complaint of students who objected to some of the purposes to which the funds were put. Writing for a unanimous Court, Justice Kennedy reiterated the core meaning of Rust by noting, "When the Court speaks, for instance to promote its own policies or to advance a particular idea, it is, in the end, accountable to the electorate and the political process for its advocacy." 194 The Court noted further that when the government speaks, the issue of viewpoint neutrality "does not come into play." 195

This focus on religion in Rosenberger offers critical guidance to the limitations that are likely to be imposed on the government's efforts to remedy societal discrimination by relying on the spending power. Just as the government cannot exclude religions from its general publication funds, the government cannot exclude groups based solely on race, even when it is exercising its spending powers. But there the religion analogy stops because the First Amendment prohibits the government from promoting religion in a way that the government is not prohibited from promoting racial equality. ${ }^{196}$

The cases just discussed, particularly Rust and Finley, have elicited stern critical commentary from academics in large part, because the causes being promoted in the cases were generally conservative in nature and, as a result, these cases have generally been treated as part of the

194 Board of Regents of the Univ. of Wisconsin v. Southworth, 120 S.Ct. 1346, 1358 (2000).

195 Id. at 1362.

196 Similarly, the government cannot penalize religion views it disagrees with in a way that it can penalize racist or discriminatory views. See Robert Tuttle \& Ira C. Lupu, The Distinctive Place of Religious Entities in Our Constitutional Order, at 18 (unpublished manuscript on file with the author) (noting that one's religious affiliation cannot be a disqualifier for public office while membership in the American White Supremacist party can). 
Court's reactionary political doctrine. ${ }^{197}$ But it is important to emphasize that the road of conditional spending need not be a one-way street, and assuming the Court would uphold similar efforts to promote liberal causes, these cases may provide the basis to uphold a variety of measures designed to remedy societal discrimination. Imagine, for example, if the government had sought to provide funds only to clinics that provided abortion services, or if it sought to fund art that was classified as "indecent" as a means of ensuring such art received support that might not be readily available in the marketplace. Assuming these cases can be stripped of their political overtones, it is difficult to see on what grounds these conditions would be invalidated, and if this assumption proves true, then these cases may suggest that the government has broad discretion to pursue its political objectives through the use of its funds.

\section{B. Government Spending in Other Contexts.}

The cases discussed above are all broadly consistent with a diverse line of cases regulating the government's proprietary activities. The Court has held, for example, that the government can restrict its employee's speech rights in the workplace, at least with respect to speech that does not involve matters of public concern, ${ }^{198}$ and the Court has likewise freed the government from the

197 For two recent critical reviews of the Court's doctrine see Steven J. Heyman, StateSupported Speech, 1999 WiSC. L. REV. 1119; Robert C. Post, Subsidized Speech, 106 YALE L.J. 151 (1996). For critiques of Rust v. Sullivan see David Cole, Beyond Unconstitutional Conditions: Charting Spheres of Neutrality in Government-Funded Speech, 67 N.Y.U. L. REV. 675 (1992); Christina E. Wells, Abortion Counseling as Vice Activity: The Free Speech Implications of Rust $v$. Sullivan and Planned Parenthood v. Casey, 95 Colum. L. Rev. 1724 (1995).

198 When a government employee is disciplined for speech that involves a matter of public concern, the Court applies a balancing test to determine whether the government was justified in its belief that the speech would interfere with the efficient operation of the government's business. See Rankin v. McPherson, 483 U.S. 378 (1987). Where the speech does not implicate a matter of public concern, there is no First Amendment restriction on the government's ability to regulate employee speech. See Waters v. Churchill, 511 U.S. 661 (1994). 
constraints of the commerce clause when it acts as a participant, or purchaser, in a market as distinct from when it is operating in its role as a market regulator. ${ }^{199}$ The government is also free to attach various funding conditions only remotely germane to the underlying purpose of the funding. For example, the federal government has required states to establish a nationwide speed limit and to set a drinking age as a condition for receiving federal highway funds, two conditions the government would likely lack the power to accomplish absent the funding hook. ${ }^{200}$ In these cases, once the government ties the conditions to government funds the Court's review has been exceedingly deferential.

\section{South Dakota v. Dole.}

The leading case in this area is South Dakota v. Dole where the Supreme Court upheld the government's decision to withhold a portion of federal highway funds from states that had a drinking age under twenty-one. ${ }^{201}$ Quoting from the Court's earlier decision in Fullilove, Chief Justice Rehnquist wrote: "Congress may attach conditions on the receipt of federal funds, and has repeatedly employed the power 'to further broad policy objectives by conditioning receipt of federal moneys upon compliance by the recipient with federal statutory and administrative directives."'202 If South Dakota wanted to keep its

199 See South-Central Timber Develop., Inc. v. Wunnicke, 467 U.S. 82, 93 (1984) (“Our cases make clear that if a state is acting as a market participant, rather than as a market regulator, the dormant commerce clause places no limitation on its activities.”).

200 See South Dakota v. Dole, 483 U.S. 203 (1987) (upholding federal highway funds tied to national drinking age); Nevada v. Skinner, 884 F.2d 445 ( $9^{\text {th }}$ Cir. 1989), cert. denied, 493 U.S. 1070 (1990) (upholding legislation withholding federal funds from states that did not impose a 55 mile-perhour speed limit).

201 South Dakota v. Dole, 483 U.S. 203 (1987).

202 Id. at 206 (quoting Fullilove v. Klutznick, 448 U.S. 448474 (1980)). 
drinking age at 19 , all it was required to do was forego some its allotted federal funds. ${ }^{203}$

Yet, the government was not entirely free to impose conditions on its funds, and much as it did in Rust, the Court established four limitations on the government's spending power. First, the spending had to be in pursuit of the general welfare, and the condition had to be stated unambiguously to provide adequate notice to fund recipients. Additionally, the condition must be related to the projects for which the funds were to be used, though how related was left undefined, and must not violate other constitutional provisions, such as if the government sought to require states to inflict cruel and unusual punishment as a condition of receiving federal funds. ${ }^{204}$ None of these limitations, however, stands as a significant barrier to conditional funding. The first two conditions - the pursuit of the general welfare stated unambiguously - are generally easily satisfied, and the fourth condition essentially restates the unconstitutional conditions doctrine, an issue that will be discussed in more depth shortly. ${ }^{205}$ The Court has likewise failed to treat the third condition on how related the conditions must be to the underlying project with anything more than a deferential eye. As Justice O'Connor argued in her dissenting opinion, there was no clear link to having a national drinking age and the provision of federal highway funds. ${ }^{206}$

Additionally, the Court suggested that some conditions might be so coercive as to result in an impermissible level of compulsion, though the Court failed to offer any guidance on when such a

203 Id. at 211 (noting that "all South Dakota would lose if she adheres to her chosen course as to a suitable minimum drinking age is $5 \%$ of the funds ...").

204 Id. at 207-08.

205 See infra section III.C.

${ }^{206}$ Id. at 213-14 (O’Connor, J., dissenting). Professor Baker has suggested that the Court adopt Justice O'Connor's more restrictive approach so as to align the spending decisions with the Court's more recent state sovereignty cases. See Baker, supra note 150, at 1962-63. 
circumstance might arise. Given that only five percent of federal highway funds were being withheld, the South Dakota case was a relatively easy one but it is also difficult to see how withholding a higher percentage of highway funds might have amounted to compulsion. After all, Rust v. Sullivan involved withholding one hundred percent of the federal government's Title X funds, and the Court never even discussed the possibility that the recipients of the grants would be compelled to accede to the condition in order to secure the funds. ${ }^{207}$

\section{The Patronage Cases.}

An area where the Court has more closely reviewed governmental actions, and one that offers important insights into the limitations that will guide governmental efforts to remedy societal discrimination, involves various patronage practices exercised by political officeholders. Patronage practices have a long history as a traditional means of distributing governmental largesse, yet in a consistent line of cases over the last twenty-five years, the Court has restricted patronage practices to the few jobs in which political affiliation is determined to be important to the functioning of the job. ${ }^{208}$ With only a few exceptions, the Court has clearly stated that an individual's political affiliation, which is treated as existing at the core of the First Amendment, should not determine whether a government employee is

207 The government's legislation mandating a 55-miles-per-hour speed limit withheld $95 \%$ of federal funds from noncomplying states. See Nevada v. Skinner, 884 F.2d 445, 454 (9 ${ }^{\text {th }}$ Cir. 1989), cert. denied, 493 U.S. 1070 (1990)

208 See Rutan v. Republican Party of Illinois, 497 U.S. 62, 78 (1990) (“Under our sustained precedent, conditioning hiring decisions on political belief and association plainly constitutes an unconstitutional condition, unless the government has a vital interest in doing so.'); Branti v. Frankel, 445 U.S. 507, 518 (1980) (holding that the government can take account of political affiliation only when "party affiliation is an appropriate requirement for the effective performance of the public office involved."). For an overview of the patronage cases see Cynthia Grant Bowman, The Law of Patronage at the Crossroads, 12 J. LAw \& Politics 341 (1996). 
able to retain or secure a government job or contract. ${ }^{209}$ Importantly, this prohibition does not stem from either history or the constitutional text, as patronage practices have long been a part of politics and it was not until the Court stepped up its review in the 1970s that the practices were thrown into constitutional doubt. ${ }^{210}$ Rather, the Court's focus has been on insulating individuals from political pressures in their employment, which the Court sees as an evil to be protected against because it seems inimical to their sense of justice and fairness in modern employment practices.

This line of cases has notably raised the ire of Justices Scalia and Rehnquist, the two most avid supporters of the government's discretionary spending power. These two Justices, who are occasionally joined in their opinions by other conservative Justices, would apply a very lenient rational basis review to restrictions applied to governmental employment practices,${ }^{211}$ which may suggest their potential openness to allowing the government to use its funds to remedy societal discrimination. But this line of cases again provides some indication of the limits on the government's powers, as the

209 See O'Hare v. City of Northlake, 518 U.S. 712 (1996) (applying political affiliation caes to independent contractors); Rutan v. Republican Party of Illinois, 497 U.S. at 80 (restricting patronage practices in promotions and transfers); Elrod v. Burns, 427 U.S. 347 (1976) (plurality opinion) (restricting elected Sheriff's ability to replace sheriff deputies based on party affiliation). See also United States v. National Treasury Employees Union, 513 U.S. 454 (1995) (invalidating government ban on honoraria for speeches and publications by government employees).

210 The history and importance of political patronage is detailed in Justice Scalia's dissenting opinion in Rutan v. Republication Party of Illinois, 497 U.S. at 104-10 (Scalia, J., dissenting).

211 See Rutan v. Republican Party of Illinois, 497 U.S. at 92 (Scalia, J., dissenting) ("When dealing with its own employees, the government may nto act in a manner that is 'patently arbitrary or discriminatory', but its regulations are valid if they bear a 'rational connection' to the governmental end sought to be served."). Justice Scalia, generally joined by Chief Justice Rehnquist, has dissented from all of the government patronage cases decided during his tenure on the Court. See United States v. National Treasury Employees Union, 513 U.S. at 489 (Rehnquist, C.J., dissenting); O'Hare v. City of Northlake, 518 U.S. at 726 (Scalia, J., dissenting). 
patronage cases provide a bright line rule to protect important political concepts embodied in the First Amendment, and I will suggest that a similar principle should direct the courts' analysis of governmental efforts to remedy societal discrimination.

\section{The Unconstitutional Conditions Doctrine.}

As we have seen, the government's discretion to use its spending power is exceptionally broad, though not unlimited, and the government funding cases suggest that the primary restriction on the government's ability to use its funding power involves what is known as the unconstitutional conditions doctrine, a doctrine that prohibits the government from requiring individuals, or entities, to forego or violate constitutional rights in order to receive federal funds. ${ }^{212}$ The doctrine, which has been applied most vigorously in the First Amendment context, has been the subject of a torrent of scholarly criticism and has been aptly described by various commentators as being either incoherent or insignificant, or both. ${ }^{213}$ To give but one example of the incoherency of the doctrine, all of the cases already discussed especially Rust and Finley - could be classified as unconstitutional conditions cases, insofar as the challenges in each of the cases was premised on a purported constitutional violation. Indeed, in both Rust and Finley the unconstitutional conditions doctrine was raised explicitly either in the Court's opinion or in the briefs filed with the Court, though ultimately the doctrine played no significant role in the Court's

212 See Laurence Tribe, American Constitutional Law $§ 5.6$ (3d ed. 2000).

213 For two forceful arguments that the doctrine is ultimately incoherent see Frederick Schauer, Too Hard: Unconstitutional Conditions and the Chimera of Constitutional Consistency, 72 DENV. U. L. REV. 989 (1985) (arguing that the unconstitutional conditions doctrine is not amenable to doctrinal reconciliation); Cass R. Sunstein, Why the Unconstitutional Conditions Doctrine is an Anachronism (With Particular Reference to Religion, Speech and Abortion), 70 B.U. L. REV. 593 (1990) (arguing that the doctrine should be abandoned). 
determination. ${ }^{214}$ This is consistent with the way in which the doctrine typically operates, and it is perhaps best to see the doctrine as derivative of the government's spending power, one that has a limited scope that rarely serves as an impediment to governmental action, particularly in recent years. ${ }^{215}$ A review of several of the paradigmatic unconstitutional conditions cases will demonstrate that the doctrine's restraint offers little beyond the Court's underlying constitutional doctrine.

The modern unconstitutional conditions doctrine is often traced to the McCarthy era case, Speiser v. Randall, where the Supreme Court invalidated a California statute that required veterans to execute a loyalty oath in order to qualify for a property-tax exemption. ${ }^{216}$ This case is said to illustrate the unconstitutional conditions doctrine insofar as it held that the state could not require a loyalty oath as a condition for receiving a property-tax exemption, ${ }^{217}$ but this interpretation misreads an

${ }^{214}$ This was particularly true in Finley where the Court failed to even discuss the doctrine. See Schauer, supra note 180, at 104 ("That the principle of unconstitutional conditions is not so much as mentioned in ... Finley is less an oversight than an epitaph.).

215 Based on this understanding, the unconstitutional conditions doctrine is analogous to the common law employment-at-will principle. The employment- at-will principle is often stated broadly, implying that an employer is free to fire an employee for any reason or no reason at all. Historically, the broadly stated rule had more resonance, but even then it was often circumscribed by various other legal obligations. See Mark Rothstein \& Lance Liebman, Employment Law $910-12$ ( $4^{\text {th }}$ ed. 1998). But today this broad version of the rule is inaccurate; a more accurate rendition would be that an employer is free to fire an employee for any reason or no reason so long as the reason does not violate some other governing legal rule, such as a statute or constitutional provision. Understood in this fashion, the employment-at-will rule provides a background understanding so that there is no independent restraint on an employer's business decision, although the employer must comply with other applicable legal strictures. The unconstitutional conditions doctrine works in the same manner: while the concept itself has no independent content, the government must comply with other constitutional provisions.

${ }^{216}$ Speiser v. Randall, 357 U.S. 513 (1958).

${ }^{217}$ Nearly every survey of the unconstitutional conditions doctrine begins with a discussion of Speiser v. Randall. See, e.g., Heyman, supra note 197, at 1123 (discussing Speiser). 
important aspect of the case. While the Supreme Court spoke broadly in a manner that has since been associated with the unconstitutional conditions doctrine, the decision was actually based on the statute's inadequate procedural safeguards. In particular, the Court was especially concerned by the fact that the burden of proof to establish fidelity to the oath fell on the person seeking the exemption. ${ }^{218}$ In fact, the Court devoted little more than a single sentence to the question whether the government could condition a privilege on the loyalty oath, and instead considered the statute under the particular law that had developed regarding loyalty oaths and political speech more generally. ${ }^{219}$ Indeed, the Speiser case was complicated by the fact that the Supreme Court had previously upheld, on several occasions, loyalty oaths for government and union jobs. ${ }^{220}$ What was different about the statute at issue in Speiser was the burden imposed on those seeking the exemption, rather than the oath itself. As a result, what the individuals were actually giving up were procedural protections incident to their First Amendment rights rather than the rights themselves

More recently, the doctrine was invoked in the case of Federal Communications

Commission v. League of Women Voters, when the government sought to prohibit public

${ }^{218}$ In an opinion written by Justice Brennan, the Court held, “[W]hen the constitutional right to speak is sought to be deterred by a State's general taxing program due process demands that the speech be unencumbered until the State comes forward with sufficient proof to justify its inhibition .... [T]hough the validility of $\S 19$ of Art. XX of the State Constitution be conceded arguendo, its enforcement through procedures which place the burdens of proof and persuasion on the taxpayer is a violation of due process." 357 U.S. at 528-29.

219 Id. at 530.

${ }^{220}$ Although loyalty oaths are often treated as anathema to the First Amendment, the Supreme Court has upheld many such oaths, and most government employees are still administered such an oath today. See Cole v. Richardson, 405 U.S. 676 (1972) (upholding Massachusetts loyalty oath and reviewing existing doctrine). . 
broadcasting stations that received federal funds from editorializing or supporting political candidates. ${ }^{221}$ Although the Court upheld the ban on supporting political candidates without any significant discussion, ${ }^{222}$ it invalidated the editorial proscription because, according to the Court, it was not narrowly tailored to support the asserted interest of protecting the stations from becoming beholden to the government. ${ }^{223}$ Additionally, the Court found that because the restriction was not limited to the use of federal funds, which provided only a small portion of the stations' budgets, it was unnecessarily overbroad, extending to the very the heart of the First Amendment's protection of political speech.

Like Speiser, the League of Women Voter's case does not offer a substantial limitation on the government's use of funds given that the case was decided under the Court's First Amendment doctrine as applied to broadcasting, rather than on the government's ability to use its federal funds, a point underscored by Justice Rehnquist's strong dissenting opinion which would have upheld the restriction as rationally related to the government's stated objective. ${ }^{224}$ And like Speiser, this case

${ }^{221}$ Federal Communications Comm'n v. League of Women Voters, 468 U.S. 364 (1984).

222 Id. at 382.

${ }^{223} I d$. at 398. The government's rationale used to justify the statute was quite peculiar and difficult for the Court to sustain under any substantive form of review. The government argued that the ban on editorials was necessary so that the stations would not seek to curry favor with the government that doled out the funds, suggesting that the stations might be too prone to praise the government in order to obtain federal funds. $I d$. Given that the government rarely seems concerned about receiving too much positive press, this noble objective, which clearly could have been met through less restrictive means, was difficult to take too seriously.

${ }^{224} I d$. at 406-07 (Rehnquist, J., dissenting). Cass Sunstein has previously argued that the unconstitutional conditions doctrine rarely adds anything to the Court's existing jurisprudence, particularly in the First Amendment context. See Sunstein, supra note 213, at 605 ("A welfare program limited to Democrats is unconstitutional because of the first amendment ... Courts do not need an unconstitutional conditions doctrine in order to make the necessary response.”). 
directly suppressed speech and therefore presented a particularly strong case for judicial invalidation. In contrast to these two cases, the Court has upheld a prohibition on substantial lobbying by tax-exempt organizations under the theory that the government was under no obligation to subsidize lobbying. ${ }^{225}$ On the surface, this case appears quite similar to the government's ban on editorializing, though a majority of the Court distinguished the two situations because tax-exempt organizations were free to establish separate non-tax exempt entities to lobby, whereas it was practically infeasible for broadcast stations to create separate stations to pursue their editorial interests. ${ }^{226}$

There are additional cases that would demonstrate the limited utility of the unconstitutional conditions doctrine, ${ }^{227}$ but the two paradigmatic cases just discussed should suffice to demonstrate just how limited the doctrine actually is. Both Speiser and the League of Women Voters' cases were decided under the Court's applicable First Amendment doctrine and therefore received little assistance from the unconstitutional conditions doctrine. In other words, these are First Amendment cases, not unconstitutional conditions cases, and there is indeed little to be gained by referring to the

225 Regan v. Taxation With Representation, 461 U.S. 540, 545 (1983) (noting that "Congress has merely refused to pay for the lobbying out of public moneys").

${ }^{226}$ FCC v. League of Women Voter's, 468 U.S. at 400 ('“[I]n contrast to the appellee in Taxation With Representation, such a station is not able to segregate its activities according to the source of its funding.").

227 Another case that is routinely treated as raising concerns under the unconstitutional conditions doctrine lends itself to a similar analysis. In Arkansas Writers' Project v. Ragland, 481 U.S. 221 (1987), the Supreme Court struck down an Arkansas tax that applied to general interest magazines but not to newspapers, religious and sports magazines. The tax, which apparently applied to only three periodicals in the state, was invalidated under what the Court referred to as its doctrine relating to "taxation of the press." Id. at 228. This case gives credence to Fred Schauer's claim that the Court is increasingly moving toward institutionally specific First Amendment doctrine. See Schauer, supra note 180 , at 104-06. 
doctrine in search of particular substantive content. Moreover, the Court's concern with what might are described as unconstitutional conditions appears most robust when the governmental restrictions extend beyond the purposes of the funds. For example, the Court would almost certainly invalidate a statute that prohibited artists who received federal grants from creating indecent art, just as the Court would invalidate a statute that prohibited individuals who received Title $\mathrm{X}$ funds from advocating abortion outside of the clinic's work. The Court has likewise protected government employee's political affiliations and speech rights outside of the workplace where the government's interest in the use of its funds is far more tenuous. ${ }^{228}$

Together the government funding cases, in conjunction with the unconstitutional conditions doctrine, provide the government with substantial latitude to shape social and economic policy through its spending power. The question that remains is whether an argument can be crafted from these cases that would allow the government to take greater measures to remedy societal discrimination than the Court has previously permitted, an issue that is discussed in the next section.

\section{The Spending Power as Applied to Race.}

The government funding cases compel the conclusion that the government can require more of its fund recipients than the constitution would otherwise require so long as the conditions are consistent with pertinent constitutional strictures. As a practical matter, these cases indicate that the primary proscription on the government's use of funds to further racial equality will lie in the Equal Protection clause, which to date has provided the primary barrier to government efforts to remedy

228 See, e.g., United States v. National Treasury Employees Union, 513 U.S. 454 (1995) (invalidating government ban on honoraria for speeches and publications of government employees). 
societal discrimination. Yet, the government funding cases, particularly Rust v. Sullivan, likewise suggest that when the government chooses to subsidize activities or chooses sides on controversial issues, the government's action is freed from the often fatal restraints of the Court's strict review and is instead subject to a form of rational basis review, under which most programs are upheld. ${ }^{229}$ We also saw that in the contract set-aside cases, the standard of review often determined the outcome when the government sought to take affirmative measures to remedy societal discrimination: strict review proved fatal, while an intermediate review offered more room for remedial governmental efforts.

In this section, I will argue that the government funding cases permit the government to take efforts to remedy societal discrimination, so long as the efforts do not rely on race-specific quotas. To illustrate this point, I will discuss how the funding cases impact contract set-aside provisions, and how those provisions might be reconfigured so as to survive the Court's scrutiny under the government's spending power even where there is no demonstrated history of discrimination by the particular governmental entity. In other words, I will contend that by restructuring the programs to focus on the diversity of the workforce rather than the race of the owners, and by tying the programs to the government's spending power, courts should uphold the programs under a rational basis review. I will also argue that the funding cases can help sustain existing government programs, and provide the means by which the government can require federal contractors to remedy practices that have a disparate effect under various spending initiatives, including Title VI of the Civil Rights Act of 1964. Accordingly, although the government funding cases do not free government programs from judicial scrutiny, they do offer a way in which certain programs can be sustained that would otherwise be invalidated but for the

${ }^{229}$ See supra text accompanying notes 152-77. 
conditional government spending. At the same time, it is important to note that the funding cases offer an imperfect fit for analyzing racially motivated programs, in large part because the affirmative action doctrine has developed independent of the government funding line of cases and the Court's antidiscrimination doctrine tends to operate within rigidly defined categories. ${ }^{230}$ Accordingly, the government funding cases will serve primarily to offer an analogous situation rather than a strict doctrinal application. $^{231}$

\section{A. The Contract Set-Asides.}

\section{Existing Set-Aside Programs and Government Spending.}

Before exploring how the government funding cases might alter the analysis for contract set-aside legislation, it is necessary to establish that the government funding cases can offer guidance in the area of race discrimination, and here Rust $v$. Sullivan provides the best analogy. It is by now accepted constitutional mantra that race is different from other constitutional matters, and this principle might suggest that the funding cases are inapposite when the government seeks to use its spending power on matters involving race. Yet, as a constitutional matter, race is more similar to abortion than it is different, and there is no particular reason the Court's rationale in the funding cases should not be extended to racially motivated funding conditions. Outside of the context of government funds, abortion is treated as implicating the fundamental right to privacy that arises from the due process clause of the

${ }^{230}$ For an engaging discussion regarding the limits of the Court's doctrine as applied to racial profiling see Brown v. City of Oneonta, 235 F.3d 769, 779 ( $2^{\text {nd }}$ Cir. 2000) (Calabresi, J., dissenting from denial of en banc review).

231 As noted earlier, only Fullilove mentioned the government's spending power, though the case was not decided on that basis, and Justice O'Connor obliquely alluded to the city's spending power in her Croson opinion. See supra text accompanying notes 52 and 84. 
Fourteenth Amendment, and regulations on abortion have always been subject to a form of strict scrutiny - the same level of scrutiny that applies in the race discrimination context. ${ }^{232}$ Although the two tests differ somewhat, the important principle here is that government funding decisions that implicate abortion are not subject to the Court's strict scrutiny, even though the underlying issue would be. This was made clear when the Court upheld governmental determinations not to use medicaid funds to pay for medically necessary abortions even though most other medically necessary treatments were covered by the funds. ${ }^{233}$ Although neither the majority nor dissenting opinions addressed the issue, it seems highly unlikely that the spending restrictions would have survived the Court's strict level of review, although they satisfied the Court's deferential review under the government's spending power. ${ }^{234}$

The case for advancing racial equality through the government's spending power is, in fact, much stronger than the government's ability to promote a distinctive view on abortion or childbirth. Arguably, under the constitution, the government should remain neutral with respect to abortion, and certainly there is nothing in the constitution that would compel the government to choose one side or the other in the abortion debate, so long as the government does not establish what would amount to an

232 See Planned Parenthood v. Casey, 505 U.S. 833 (1992).

233 See Harris v. McCrae, 448 U.S. 297, 324 (1980) (applying rationality review to federal legislation prohibiting use of medicaid funds for abortions); Maher v. Roe, 432 U.S. 464, 478 (1977) (upholding state regulation that refused to allow medicaid funds to be used for abortions noting that "[w]e think it abundantly clear that a State is not required to show a compelling interest for its policy choice").

${ }^{234}$ Denying poor women the right to obtain a constitutionally protected procedure as a way of pursuing a legitimate governmental objective would not likely be defined as rising to the level of a compelling interest. Surely the government cannot have a compelling interest in denying low-income women their fundamental rights, though it might be rational if the government opts to pay for such procedures. 
undue burden on women's right to exercise their fundamental right to an abortion. ${ }^{235}$ But the same is not true with racial equality where the government is not charged with neutrality but is instead commanded to take sides, a principle the Supreme Court has reaffirmed on many occasions. ${ }^{236}$ The government has a constitutional mandate to eradicate discrimination and to refrain from participating in the private manifestation of racial bias, and its mandate extends far beyond a claim of neutrality on racial discrimination. ${ }^{237}$ Nor could the government express indifference towards the presence of societal discrimination; instead it is plainly obligated to try to eradicate all such discrimination. Indeed, when it comes to matters of racial equality, the government's side has already been chosen by the constitution's promise embodied in the Equal Protection clause, and it is the side devoted to eliminating all forms of racial discrimination.

This does not mean, however, that the government can use its funds to pursue racial equality in an unrestricted manner or that the court should simply defer to the government's political decisions that are tied to the spending power. As noted earlier, the Equal Protection Clause still stands as a barrier to governmental funding decisions, but it is an Equal Protection Clause that, under the

235 See Planned Parenthood v. Casey, 505 U.S. at 884-85.

236 See, e.g., Bob Jones University v. United States, 461 U.S. 574 (1983) (upholding the IRS' decision to deny tax exemption to racially discriminatory schools); Norwood v. Harrison, 413 U.S. 455, 469 (1973) ("'AA]lthough the Constitution does not proscribe private bias, it places no value on discrimination ..." $)$.

237 See Croson, 489 U.S. at 504 (holding that the government can seek to remedy its own participation in discrimination); Palmore v. Sidoti, 466 U.S. 429 (1984) (holding that private "biases may be outside the reach of the law, but the law cannot, directly or indirectly, give them effect."); Norwood v. Harrison, 413 U.S. at 465 (" $[\mathrm{I}] \mathrm{t}$ is ... axiomatic that a state may not induce, encourage, or promote private persons to accomplish what is constitutionally forbidden to accomplish.”). 
government funding cases, would be interpreted outside of the Court's strict level of scrutiny. What that means as a practical matter is more difficult to define, as indicated by the discussion of the unconstitutional conditions and governmental funding cases where no clear doctrinal principle emerges despite the volume of cases and extensive scholarly literature. ${ }^{238}$

My own reading of the doctrine is that the political patronage cases provide the best analogy for how the Court ought to proceed when analyzing governmental spending programs that are intended to remedy societal discrimination. In the political patronage cases, the Court has drawn a blunt line prohibiting the hiring of all but high-level officials based on their political affiliation, and it has done so not because either our history or something in the constitution so mandates, but because it seems inimical to the Court that ordinary employment decisions would turn on a person's political affiliation. ${ }^{239}$ By the same measure, there seems to be widespread agreement that the government could not award government funds - whether they be for contracts, the arts, or any other area - based on political affiliation, by funding only Republican contractors or artists, just as they could not restrict funds for abortions to Republican or Democratic women. ${ }^{240}$

238 Erwin Chemerinsky makes this point nicely in a lecture delivered at the Cleveland-Marshall Law School regarding governemntal content-based choices. See Erwin Chemerinsky, The First Amendment: When the Government Must Make Content-Based Choices, 42 CLEV. ST. L. REV. 199 (1994). Chemerinsky writes: "Increasingly, I came to see that some of the hardest First Amendment issues, the ones most dividing lower courts and perplexing commentators involved instances in which the government had to make content-based choices. The more I looked the more cases and examples I found. Yet, as I read the cases, I found the analysis terribly unsatisfying. All used traditional First Amendment principles and they seemed of little help." Id. at 200.

239 See note 210 supra.

240 See, e.g., Greene, supra note 7, at 38-40 (discussing various restrictions on the government's power to shape social and political life). 
This same analysis should apply in the area of awarding contracts or providing government funds on the basis of race. The government clearly cannot decide to provide funds only to African Americans or to whites, or any other racial or ethnic group, absent proof that the funds were being used as a remedial tool to address identifiable discrimination. This principle arises from the Court's current antidiscrimination doctrine ${ }^{241}$ and this part of the doctrine would not be affected by the government funding cases, as would also be true with respect to the Court's doctrine prohibiting racial quotas, a principle the Court has restated consistently and frequently. ${ }^{242}$ Although the Court has never strictly applied a "colorblind" interpretation of the Fourteenth Amendment, outside of several remedial programs where the defendant's discrimination had been well-documented ${ }^{243}$ the Court has never upheld a quota tied to race and it has expressed great hostility to the notion that race should be used in such a strong fashion, going so far as to equate race-conscious redistricting to a form of apartheid. ${ }^{244}$ Given that the Court's prohibition on racial quotas would continue even if the principles of the government funding cases were applied to government efforts to combat societal discrimination, it is important to see that the Court's proscription on racial quotas does not stem from the level of review

${ }^{241}$ See Croson, 488 U.S. at 509-10.

${ }^{242}$ See Selmi, supra note 99 , at 344-46.

${ }^{243}$ See United States v. Paradise, 480 U.S. 149 (1987); Local 28 of Sheet Metal Workers' International Ass'n v. EEOC, 478 U.S. 421 (1986). The Court has also upheld a voluntary affirmative action plan where the clear racial disparities in hiring had not been attributed to the employer, much like the situation in the Johnson case discussed earlier. See United Steelworkers v. Weber, 443 U.S. 193 (1979).

244 See Shaw v. Reno, 509 U.S. 630, 647 (1993) ("A reapportionment plan that includes in one district individuals who belong to the same race, but who are otherwise widely separated by geographical and political boundaries, and who may have little in common with one another but the color of their skin, bears an uncomfortable resemblance to political apartheid."). 
that the Court applies but is instead based on the Court's understanding of what the Equal Protection clause means. Racial quotas are antithetical to the Court's interpretation of the Equal Protection clause, just as making ordinary political hiring decisions based on political affiliation is antithetical to core First Amendment principles.

This interpretation may explain why the government funding cases have not previously been employed in the contract set-aside cases. On first blush, it might appear that these cases especially Croson and Adarand - should be treated as government funding cases since they involve the government's use of its funds on construction and other business projects. But because the programs have generally been structured in a way that sought to ensure a fixed percentage of government dollars went to minority contractors, or in the case of Metro Broadcasting by creating strong preferences for broadcast licenses, these cases would run afoul of the unconstitutional conditions doctrine to the extent the Court construes the program as setting aside federal dollars, or broadcast licenses, for African Americans. ${ }^{245}$ Explicitly setting aside dollars based on race represents the kind of program that conflicts with the Equal Protection clause even where government funding is at issue because the government simply cannot award contracts to a particular race based on its race. ${ }^{246}$

245 The set-aside program for the City of Richmond established a goal of awarding thirty percent of city contracts to minority contractors, although the city consistently awarded less than the goal. See Drake \& Holsworth, supra note 120, at 82-83.

${ }^{246}$ I should be clear that it is the Court's perception that the set-aside cases amount to quotas, a perception I disagree with. As noted previously, the contract programs establish goals rather than rigid quotas and those goals are rarely fully satisfied. At the same time, tying the contract programs to the funding cases may provide an interesting challenge for the Court. The two strongest proponents of the government's power to use its funds in a largely unrestricted manner are Justices Rehnquist and Scalia, both of whom have yet to identify a governmental string that they did not find constitutionally permissible. Yet, they are also the strongest opponents of the government's efforts to remedy racial 
Before moving to a discussion regarding the role these cases might have on the Court's discrimination doctrine, I want to pause for a moment to pursue the question further why cases such as Rust and Finley have not previously been applied in the antidiscrimination area. ${ }^{247}$ The most likely reason, I believe, is that these cases have largely been regarded as the product of conservative causes and therefore have been treated as politically conservative cases that are hostile to liberal causes such as remedying discrimination. ${ }^{248}$ There is obviously some truth to this argument: both Rosenberger and Rust were decided by a five-member majority that broke down on traditional conservative/liberal lines and Rust and Finley were clearly aligned with conservative causes. It is equally clear that the Court likely would have been unwilling to uphold the government regulation in Rust if the presumption underlying the program had been reversed, if for example, the government was only willing to allocate funds to health clinics that provided abortion services. But, in light of the Court's resolution in Rust, it would be difficult to distinguish programs that expressed different political preferences, and I think it is a mistake to treat these cases as simply implementing conservative political programs. Once the cases are shed of their conservative overtones, it is apparent that the Court has turned over broad discretion to governments to

inequality, voting against all such programs that have come before them. Justice Rehnquist was even the lone dissenter in the notorious Bob Jones case. See Bob Jones University v. United States, 461 U.S. 574, 592 (1983) (Rehnquist, J., dissenting). It is likely that their antipathy for race conscious measures would override their apparent sympathy for governmental spending powers, but it would not be an easy opinion to write, and it is certainly possible that so long as the government funds did not seek to institute racial quotas even these Justices would vote to affirm the government's power.

247 Among commentators, only Owen Fiss has noted a possible connection, though his discussion was limited to the broadcast licensing case, Metrobroadcasting. See OwEn M. FISS, ThE IRONY OF FREE SPEECH 76 (1996) (suggesting that Metrobroadcasting was a product of the Court's constitutional indifference to allocation decisions).

248 For one such treatment see Heyman, supra note 197, at 1128. 
pursue their political objectives, and these cases are best seen as affording broad judicial deference to the political process, a deference that should extend to efforts designed to remedy societal discrimination.

\section{Reconfiguring the Set-Aside Provisions.}

In order for government set-aside programs to benefit from the government funding cases, the programs would have to be reconfigured to diminish their race consciousness. As noted earlier, despite various provisions in the programs that allowed for waivers or exemptions from the statutory requirements, the Supreme Court has typically treated the set-aside cases as involving racial quotas that have not survived the Court's strict level of scrutiny. ${ }^{249}$ One way the government might seek to achieve an acceptable result would be to reconfigure the contract set-aside programs to reward employers for having a diverse workforce, rather than by seeking to distribute funds based on the race of the owners. Reconfigured in this way, the contract program might give a preference to those employers who have a diverse workforce as measured by current industry standards. The preference could be in the form of a bid credit so that a contractor who exceeded the industry standards would be entitled to a credit worth up to ten or twenty percent of the contract price, which would typically allow the contractor to underbid its competitors. ${ }^{250}$ By providing such a preference, the government would merely be choosing to deal with a business that takes racial justice seriously, that has demonstrated a

${ }^{249}$ See text accompanying notes 79-84

250 See Ian Ayres, Narrow Tailoring, 43 UCLA L. Rev. 1781, 1809-11 (1996) (discussing bid credits). Both of these measures are distinct from providing a preference to the most diverse workforce of the bidders, which may seem to the Court as if the government is preferring race rather than rewarding employers for having progressive hiring policies. 
sincere commitment to the hiring and advancement of minorities, and that has likewise shown a commitment to help eradicate the effects of societal discrimination.

A preference program premised on the diversity of the workforce would differ significantly from most existing governmental set-aside programs. Currently, most government programs provide various preferences to contractors based on the ownership of the company, with the typical standard requiring that the company be at least fifty-one percent owned by minority or disadvantaged individuals. $^{251}$ These programs are intended to overcome discrimination in the contracting industry, as well as to encourage entrepreneurship, and shifting the focus away from ownership and onto the composition of the workforce would serve slightly different goals by concentrating on combating the effects of hiring discrimination and other discriminatory barriers that have hindered entry into the contracting industry. The change in focus would also help address two problems that have long plagued existing set-aside programs. When the ownership of the business triggers the preference, it is not uncommon for entities to affiliate with minorities in order to qualify for a contract or a bid preference. Those who have affiliated in order to assist the company in qualifying for preference programs were often well-known figures or wealthy ones, and they often had little ultimate interest in or connection to the underlying project. ${ }^{252}$ There are ways to protect against these difficulties, and the federal transportation program has been altered so as to impose limits on the net worth of the company that can

251 This is true of the existing federal contracting program operated under the auspices of the Department of Transportation. See 15 U.S.C. $\$$ 637(a); 49 C.F.R. 26.67.

${ }^{252}$ For a discussion of the problems that arise over sham corporations see Ian Ayres \& Peter Cramton, Deficit Reduction Through Diversity: How Affirmative Action at the FCC Increased Auction Competition, 48 St An. L. Rev. 761, 807 \& n.153 (1996). 
qualify as a disadvantaged business, ${ }^{253}$ but having the preference turn on the diversity of the workforce will spread the benefits of the program more broadly and avoid some of the concerns regarding whether the recipient is truly deserving of the benefit. ${ }^{254}$ Emphasizing workforce diversity as opposed to the nature of the ownership will also avoid concerns regarding the existing presumptions that typically presume that members of certain minority groups are "disadvantaged" and therefore eligible for the program's preferences. ${ }^{255}$

If the program were restructured in this way, it is difficult to see what the constitutional objection would be. Although the program could be described as race conscious insofar as government benefits would be tied to the presence of minorities in the workplace, ${ }^{256}$ it does not involve a quota by any legitimate sense of the word as it does not guarantee a particular outcome, nor would the program require particular action by the contractor. ${ }^{257}$ Instead the government would be making a policy

253 See 49 C.F.R. 26.67(b)(1) (a net worth exceeding $\$ 750,000$ defeats the presumption of economic disadvantage).

${ }^{254}$ There is obviously a continuing debate on whether those who receive preferences of all sorts are truly deserving of them, and predicating the benefit on workforce diversity will not necessarily resolve that debate.

${ }^{255}$ See 49 C.F.R. 26.67(a).

${ }^{256}$ See Kim Forde-Mazrui, The Constitutional Implications of Race-Neutral Affirmative Action, 88 Geo.L.J. 2331, 2333 (2000) (contending that ostensibly race neutral efforts can be described as race conscious).

${ }^{257}$ One way of understanding the Court's concern with what it treats as racial quotas is that individuals or businesses are denied a reasonable opportunity to participate in the process because of their race, a concern that underlies the Court's treatment of traditional affirmative action plans and the more recent racial redistricting cases where the Court is clearly troubled by the fact that the districts are drawn to produce a particular result and generally succeed in doing so. See Selmi, supra note 99, at 317. 
decision, supported by its funds, to choose to deal with the most progressive employers in an industry, as measured by the diversity of the workforce. Restructured in this fashion, the program would largely be indistinguishable from a program that refused to provide funds to abortion providers, or that provided additional funds to those entities that specialize in aiding women to put unwanted children up for adoption, or that chose based on its content which artists to support.

One notable difference, of course, is that employers or contractors would be rewarded for the racial diversity of their hiring practices, rather than rewarding doctors or artists for their social choices. But race would not be the exclusive requirement: any employer or contractor could qualify for the program by rising above industry averages in obtaining a diverse workforce. Assuming a diverse workforce is a public good, as certainly was the rhetoric of the Clinton Administration, ${ }^{258}$ the government should be free to reward those entities that succeed in their pursuit of a common, and legitimate, social goal. Accordingly, the message embodied in the program would be that the government wants to do business not just with nondiscriminatory employers, which the law already requires, but with progressive employers, a message the government should be free to pursue through its spending powers. ${ }^{259}$

258 See Peter Baker, President Completes Second-Term Team, Wash. Post., Dec. 21, 1996, at A1 (quoting President Clinton as saying, "I believe that one of my jobs at this moment in history is to demonstrate by the team I put together that no group of people should be excluded from service to our country and that all people are capable of serving. So I have striven to achieve both excellence and diversity."); Gary L. Gregg, II, Toward A Representational Framework For Presidency Studies, 29 Presidential Studies Q. 297, 306 (1999) (noting that President Clinton's commitment to diversity needs to be considered in evaluating his efforts at political representation).

259 As discussed shortly, the government already seeks to pursue such a mission through Title VI of the Civil Rights Act of 1964, and Executive Order 11,246, both of which impose certain affirmative obligations on the recipient of federal funds including federal contractors. See infra section 
For the program to be upheld, the government would have to establish a reasonable parameter for determining when a contract bonus or preference would be awarded, as well as an explanation for why the funding condition was legitimate and related to the underlying program to which it was attached. ${ }^{260}$ On the first element, the government might reward contractors that exceed industry averages by twenty-five percent, or it might also simply choose to deal with the contractor that has established the best hiring practices within the industry. To the extent that all of the contractors have equal records no one would be entitled to a contracting preference. ${ }^{261}$ Establishing that the condition is related to the underlying program should likewise prove relatively undemanding. Here, the analysis would likely return to a focus on societal discrimination; the government would argue that it wants to reward those employers who are working to combat societal discrimination by ensuring opportunity for minority employees, and it might also be necessary to document that societal discrimination had influenced the particular industry. Under this analysis, there would be no need for the contractor to admit or establish its own past discrimination, nor would the government be obligated to document its role in perpetuating discriminatory patterns within the particular industry. Rather, the government would be using its funds to attack a known problem, and assisting private businesses in their quest to overcome the effects of societal discrimination, both past and present. Such a program would be akin to existing

III.B.

260 See South Dakota v. Dole, 483 U.S. 203 (1987).

261 One caveat should be noted. It is conceivable that an entire industry might be rife with discrimination so that even the best within the industry might be one that was acting unlawfully. Under these circumstances, no one should be entitled to a contracting preference, and indeed, the contractors would be in violation of their nondiscriminatory obligations under existing statutes. See 42 U.S.C. $\S$ 2000d (Title VI). 
unobjectionable governmental programs that provide awards to employers for their hiring practices ${ }^{262}$ except that the awards would now be monetary in nature, functionally equivalent to a subsidy.

Establishing that the programs are related to remedying societal discrimination would also alleviate any concern that the government's spending power might be used to serve contrary purposes, as there could be no legitimate rationale for a government to reward employers who had an all-white, or nondiverse, workforce. Consistent with the purposes of the Fourteenth Amendment, the government's spending power, as related to societal discrimination, would work in one direction only, and while the programs could be abolished by a hostile government, they could not be used to pursue illegitimate purposes. This highlights an important potential downside to justifying set-aside programs based on the spending power, which is that a different, more conservative, government might prefer contractors that do not have affirmative action plans. While there would be no legitimate purpose in preferring a contractor that did not have a diverse workforce, a government hostile to affirmative action might prefer to do business with contractors that did not engage in any form of affirmative action. Such a program would likely be constitutional, which may suggest that using the government spending power to remedy societal discrimination may portend some political risks, but these are the risks attendant to politics and would effectively concentrate lobbying efforts on the political branches, where at least on the federal level, efforts to prevent the repeal of existing affirmative action programs have been remarkably

262 The Department of Labor provides an annual award to a federal contractors that has "established and instituted comprehensive workforce strategies to ensure equal employment opportunity," a program that was initiated in 1988 under a Republican administration. See Department of Labor Division of Management and Administrative Programs, Employment Standards Administration Office of Federal Contract Compliance Programs Directive No. 229 (visited July 26, 2000, http://www.dol.gov/dol.esa/public/media/reports/ofcp/evedir.html). 
successful. ${ }^{263}$ Similarly, it is almost certainly the case that allowing politically progressive governments to use their spending power to enhance minority opportunities will offer more fertile conditions for racial justice than the existing regime where too much time is spent fighting to preserve the status quo rather than stretching its boundaries. ${ }^{264}$

Even a reconfigured program would likely be subject to constitutional challenges but unless the party challenging the program, likely a disappointed contractor, could establish that the successful contractor was only able to achieve a diverse workforce through unconstitutional means, the Equal Protection clause should not stand as a barrier to the governmental program. In some ways this may sound circular: only an unconstitutional program would violate the Equal Protection clause. But what I mean to suggest here is that the focus of the inquiry would be on the hiring practices of the contractor, rather than the funding requirements of the program. If the contractor is able to demonstrate that it used lawful means to achieve a diverse workforce, there would be no argument that the program encouraged or required unconstitutional conduct. Surely it would be wrong to presume that a diverse

263 Even in what would appear a quite receptive climate, over the last five years Congress has repeatedly refused to legislatively invalidate any existing affirmative action program, and the entrenchment of existing programs may offer some protection from a widespread scale back. See Jeffrey Rosen, Damage Control, New YoRKER, Feb. 23, 1998, at 58 (discussing how universities were responding to court decisions so as to preserve efforts to diversify student bodies); James Dao, Senate Stops Bid to End Road-Work Set-Asides, N.Y. Times, Mar. 7, 1998, at A9 ("In this year's first major test of Federal affirmative action policies, the Senate strongly rejected an effort today to end a two-decade old program ....”).

264 In an engaging book, Mark Tushnet has recently argued that we ought to take the constitution away from the courts and place it more solidly in the political realm. See MARK Thusnet, TAKing the Constitution Aw ay From the Courts (1999). 
workforce was the product of unconstitutional actions, or even a product of affirmative action at all. ${ }^{265}$

The D.C. Circuit Court of Appeals has arguably reached a contrary conclusion in striking down, on two recent occasions, a preference program administered by the Federal Communications Commission ("FCC"). ${ }^{266}$ The initial case involved a challenge by a church after the FCC found the church had failed to comply with the Commission's affirmative action regulations as applied to hiring, given that the church preferred to hire individuals with religious knowledge to work at its classical radio station, a practice that in this instance had a disparate effect on minorities. ${ }^{267}$ The court invalidated the government's regulations arguing that "the regulations pressure stations to maintain a workforce that mirrors the racial breakdown of their "metropolitan statistical area"" and "[a]s such, they can and surely will result in individuals being granted a preference because of their race," a preference the court held was facially unconstitutional. ${ }^{268}$ This conclusion is premised on the manifestly erroneous notion that a diverse workforce is the product of unconstitutional preferences, rather than an aggressive recruitment drive, or other practices that tend to draw in minority employees in one way or another,

265 For a lengthy discussion of various forms of affirmative action and how their structure determines their constitutionality see Shuford v. Alabama State Board of Education, 897 F.S. 1535, 1551-55 (M.D. Ala. 1995).

266 See MD/DC/DE Broadcasters Ass'n v. Federal Communications Commission, 236 F.3d 13 (D.C. Cir. 2001); Lutheran Church-Missouri Synod v. FCC, 141 F.3d 344 (D.C. Cir. 1998).

${ }^{267}$ Lutheran Church-Missouri Synod v. FCC, 141 F.3d at 346-48.

268 Id. at 352-54. More recently, the D.C. Circuit invalidated one option (option B) broadcast stations had to satisfy the FCC's regulations, an option that required affirmative recruitment efforts. See MD/DC/DE Broadcasters v. FCC, 236 F.3d at 22 (“Option B places pressure upon each broadcaster to recruit minorities without a predicate finding that the particular broadcaster discriminated in the past or reasonably could be expected to do so in the future."). 
whether by transportation subsidies or by charitable giving to minority communities. ${ }^{269}$ It is indeed a sad testament to the state of the law when an appellate court presumes that a diverse workforce can only be obtained unconstitutionally, and contrarily, that an all-white workforce is to be treated as a natural byproduct of legitimate hiring. ${ }^{270}$ Yet, even a court inclined to follow the court's reasoning need not invalidate the reconfigured contract set-aside program described above. The program administered by the FCC did not involve the government's spending power, but was instead purely an exercise in regulatory power, a power, as noted earlier, that involves an important limited resource. Moreover, the program's rationale was premised on promoting diversity in programming, the rationale that had earlier generated so much controversy in the Supreme Court's decision in Metro Broadcasting. ${ }^{271}$

There remains a question whether these reconfigured programs would survive the Court's existing Equal Protection doctrine, and if so whether adding the government funding cases significantly advances the constitutional argument. Several scholars have argued that the Supreme Court should validate, under existing doctrine, those programs that are racially motivated in the pursuit of

269 The court's decision in Luthern Church-Missouri Synod produced a stinging dissent from Chief Judge Edwards on the court's decision not to grant en banc review. He specifically contested the court's determination to apply strict scrutiny to the FCC program, noting, "The regulations in no way draw any kind of racial classification. They plainly do not 'oblige' anyone to exercise any sort of hiring preference. Rather, the regulations merely facilitate the avoidance of unlawful employment discrimination. The regulations 'influence' hiring decisions only in the sense that anti-discrimination law generally seeks to influence employers to avoid bias." Lutheran Church-Missouri Synod v. FCC, 154 F.3d 494, 497 (D.C. Cir. 1998) (Edwards, C.J., dissenting from the denial for suggestions of rehearing en banc).

270 For an analysis of the case see Michelle Adams, supra note 140, at 1426-35.

271 See Lutheran Church-Missouri Synod, 141 F.3d at 354-55; MD/DC/DE Broadcasters Ass'n v. FCC, 236 F.3d at 20; see also supra text accompanying notes 87-92 (discussing Metro Broadcasting). 
permissible governmental objectives. ${ }^{272}$ It may certainly be the case that the Supreme Court would uphold such a program even without the aid of the government funding cases, but it seems equally likely that the Court would apply strict scrutiny to the programs seeing them as both race conscious and pursuing an impermissible goal. Bringing the government funding cases into the analysis demonstrates that the programs are political programs that are legitimately structured to further the government's discretion in choosing policy goals. The government funding cases therefore add an important perspective to the issue and, if applied properly, would offer a more stable constitutional ground on which the programs could rest.

\section{B. Other Means of Remedying Societal Discrimination.}

Given the course of the Supreme Court's doctrine, turning to the spending power will likely have its greatest impact in the area of contract set-asides, ${ }^{273}$ but the government may also use its funds to pursue other means of combating societal discrimination. Indeed, the argument set forth relating to set-aside programs could easily be extended to other areas in which the federal government uses its spending power so that the government distributes its funds to those who have demonstrated a superior commitment to racial equality. In this section, I will discuss two additional possibilities, one involving an existing governmental program and some additional programs that might be created with the purpose of eradicating societal discrimination.

${ }^{272}$ See, e.g., Kim Forde-Mazrui, supra note 256, at 2382.

273 As noted earlier, see notes $3 \& 4$ supra, the inability of the government to remedy societal discrimination has led to the invalidation of dozens of set-aside programs. 


\section{Title VI, The Disparate Impact Theory, and The Spending Clause.}

Title VI, passed as part of the omnibus Civil Rights Act of 1964, is one of the least known and enforced of the civil rights statutes, though potentially one of the most important. ${ }^{274}$ In the last few years the statute has experienced a surprising renewal primarily through private enforcement actions based on varied and creative litigation strategies. ${ }^{275}$ As the litigation under Title VI has increased, there have also been a number of challenges to the statute's scope, in particular questions have been raised regarding whether the statute includes a disparate impact component. ${ }^{276}$ I will suggest that the spending power cases provide the means by which the statute can best be construed to reach practices that have disparate effects upon racial minorities, which could potentially have a far-reaching impact on the recipients of federal funds. If Title VI encompasses neutral practices that have disparate racial effects, many Universities and colleges may have to reconsider their admissions programs, especially their emphasis on standardized tests as a criterion for admission given that the tests have been demonstrated to

\footnotetext{
${ }^{274}$ For an excellent analysis of the government's limited enforcement efforts under Title VI see Stephen C. HalPern, On the Limits of the La w: The Ironic Legacy of Title VI of the 1964 Civil Rights ACt (1995).

275 Title VI litigation currently represents some of the most interesting challenges being litigated in federal courts today. See, e.g., Cureton v. NCAA, 198 F.3d 107 ( $3^{\text {rd }}$ Cir. 1999) (challenging athletic eligibility requirements); Sandoval v. Hagan, 197 F.3d 484 (1 th $^{\text {th }}$ Cir. 1999), cert. granted, 121 S. Ct. 28 (2000) (challenging state policy of providing drivers' examinations only in English); Ferguson v. City of Charleston, 186 F.3d $469\left(4^{\text {th }}\right.$ Cir. 1999) (challenging city policy of arresting or sending to drug counseling pregnant women who test positive for cocaine), cert. granted, 528 U.S. 1187 (2000); Burton v. City of Belle Glade, 178 F.3d 1175 ( $11^{\text {th }}$ Cir. 1999) (challenging city's failure to annex housing project); New York Urban League v. State of New York, 71 F.3d 1031 (2d Cir. 1995) (per curiam) (challenging increase in subway fare as disproportionately excluding minorities from transit system).
}

${ }^{276}$ See, e.g., Powell v. Ridge, 189 F.3d 387 ( $3^{\text {rd }}$ Cir. 1999), cert. denied, 120 S.Ct. 579 (1999) (holding that Title VI permits private right of action to pursue disparate impact claim). 
have significant disparate impact in many settings. ${ }^{277}$

Title VI prohibits discrimination based on race and national origin by the recipients of federal funds, and the Supreme Court has construed the statute to permit private enforcement actions in addition to governmental enforcement actions. ${ }^{278}$ Since its passage there has been a question whether the statute requires the recipients of federal funds to remedy their practices that have disparate racial effects but are not otherwise intentionally discriminatory. The Supreme Court has addressed the issue in a curious and confused manner, holding that while Title VI only prohibits intentional discrimination, the agency regulations implementing the statute can permissibly forbid discrimination based on the disparate effects of the federal contractor's practices. ${ }^{279}$ Federal regulations have for many years interpreted the

277 For a discussion regarding the disparate impact of the LSAT see Linda F. Wrightman, The Threat to Diversity in Legal Education: An Empirical Analysis of the Consequences of Abandoning Race as a Factor in Law School Admissions Decisions, 72 N.Y.U. L. REV. 1 (1997).

278 Title VI reads: "No person in the United States shall, on the ground of race, color, or national origin, be excluded from participation, be denied the benefits of, or be subjected to discrimination under any program or activity receiving federal financial assistance." 42 U.S.C. $\S$ 2000d. This Term the Supreme Court is addressing the question of the limits on private enforcement actions. See Sandoval v. Hagan, 197 F.3d 484 (11 ${ }^{\text {th }}$ Cir. 1999), cert. granted, 121 S. Ct. 28 (2000).

279 The Supreme Court has addressed the scope of Title VI on four occasions, the most recent of which was in 1985. Initially, in Lau v. Nichols, 414 U.S. 563 (1974), the Court held that Title VI encompassed a disparate impact theory, although this holding was later thrown into doubt when the Court construed Title VI to be coextensive with the Fourteenth Amendment which does not reach disparate impact claims. See University of California Regents v. Bakke, 438 U.S. 265, 287 (Powell, J.); id. at 328 (opinion of Brennan, White, Marshall, and Blackmun, JJ.). Several years later the Court arrived at a particularly tortured approach best summarized by Justice Powell: "Only Justices White and Marshall believe that a violation of Title VI may be established by proof of discriminatory effect, and Justice White would recognize only noncompensatory prospective relief for such a violation. Justices Brennan, Blackmun, and Stevens, however, believe that a violation of the regulations adopted pursuant to Title VI may be established by proof of discriminatory impact. Thus, a majority of the Court would hold that proof of discriminatory effect suffices to establish liability only when the suit is brought to enforce the regulations rather than the statute itself." Guardians Ass'n v. Civil Serv. Comm'n, 463 U.S. 
statute to include a disparate impact component, ${ }^{280}$ and the vast majority of the cases currently being filed under Title VI involve disparate impact challenges. ${ }^{281}$ As noted previously, disparate impact challenges are intended primarily to address societal discrimination, so to the extent the government can require its contractors to remedy practices that have disparate racial effects, it is effectively requiring those contractors to remedy societal discrimination.

An important question, then is whether the government through its regulatory and spending power can interpret Title VI to require the recipients of federal financial assistance to remedy practices or policies that have a disparate effect based on race or national origin, even though the terms of the statute only reach intentional discrimination. Although the existing regulations have always seemed a bit incongruous, given their apparent inconsistency with the statutory mandate, the spending clause may help solve the puzzle and explain why the regulations have generally been treated as presumptively valid even by the Supreme Court itself. ${ }^{282}$ When the spending power is introduced into the analysis, it becomes clear that the government can interpret the statutory obligations ensconced in Title VI broadly so as to ensure that its aid recipients seek to remedy discrimination defined expansively, and it does so as a means of eradicating the national problem of societal discrimination. In this respect, the Title VI

582, 608 n.1 (1983) (Powell, J., concurring). Two years later, the Court affirmed this reading by permitting a disparate impact challenge based on implementing regulations. See Alexander v. Choate, 469 U.S. 287, 293 (1985) (“actions having an unjustifiable disparate impact on minorities could be reddressed through agency regulations designed to implement the purposes of Title VI.”).

280 See, e.g., 34 C.F.R. $§ 100.3$ (b)(2) (Department of Education regulations prohibiting fund recipients from "utiliz[ing] criteria or methods of administration which have the effect of subjecting individuals to discrimination because of their race, color or national origin ....").

281 See cases cited in notes 275-76 supra, all of which involve disparate impact challenges.

282 See Alexander v. Choate, 469 U.S. 287, 293 (1985). 
regulations closely resemble the regulations upheld in Rust v. Sullivan. ${ }^{283} \mathrm{Just}_{\text {as }}$ the government did not want to expend funds in a way that might have supported or encouraged abortions, the government would here be ensuring that its funds were not used in a manner that supported discrimination of any kind. As in the funding cases more generally, no entity would be compelled to accept the government funds, and if a potential fund recipient refused to alleviate the adverse effect of its practices, it would be free to refuse the funds - just as the health clinics were free to turn away federal funds if they wanted to provide abortion counseling, or just as states could decline highway funds if they thought a national speed limit would unreasonably slow their drivers down. ${ }^{284}$

The only restriction on the government's ability to construe Title VI so as to apply to practices that had an adverse impact would be the language of the statute. But given that the Supreme Court interpreted nearly identical language under Title VII — which was passed at the same time as Title VI - to include a disparate impact cause of action, the government's administrative interpretation of Title VI would surely be deemed a reasonable one. ${ }^{285}$ Accordingly, the spending clause provides the underlying explanation for the government's power to require its contractors to remedy societal discrimination in the form of disparate impact challenges.

283 As noted earlier, the regulations at issue in Rust had been promulgated under the Reagan Administration, and were subsequently rescinded by the Clinton Administration, suggesting that an administration has broad discretion to pursue its own policy objectives so long as the interpretation is reasonable.

284 See text accompanying notes 202-03.

285 See Griggs v. Duke Power, 401 U.S. 424 (1971). 


\section{Funding Integration Efforts.}

A final area where the government could use its spending power to help eradicate societal discrimination would be to fund various integration efforts. These efforts could take many forms; for example, the government might provide additional housing funds to developments that are built in integrated areas, or that help maintain or increase housing integration. Existing cases suggest that government efforts to encourage affirmative outreach or recruitment designed to foster housing integration would likely be upheld so long as the developments did not achieve integration through impermissible racial quotas or resident balances. ${ }^{286}$ Indeed, the government currently requires the recipients of federal housing funds to comply with federal housing requirements, including creating an affirmative marketing program designed to attract minority applicants. ${ }^{287}$ A challenge to the program was recently rejected by the First Circuit Court of Appeals, though the court did not rely on the government's spending power to sustain the program. ${ }^{288}$ Under the government's spending power, these programs should surely be upheld as a valid means to pursue the legitimate goal of housing integration, and provide further proof that the government already takes various actions designed to remedy societal discrimination. The government

${ }^{286}$ Compare United States v. Starrett City Associates, 840 F.2d 1096 (2d Cir. 1988) (invalidating racial balance program designed to preserve an integrated housing complex) with SouthSuburban Housing Center v. Greater South Suburban Board of Realtors, 935 F.2d 868 (7 $7^{\text {th }}$ Cir. 1991) (upholding race-conscious marketing designed to maintain racially integrated neighborhoods). For a discussion of the constitutionality of mortgage-incentive programs intended to foster integration see Suja A. Thomas, Efforts to Integrate Housing: The Legality of Mortgage-Incentive Programs, 66 N.Y.U. L. Rev. 940 (1991) (note).

287 See 24 C.F.R. $\S \S 1.5,5.105,200.620$ (1997).

288 See Raso v. Lago, 135 F.3d 11 ( $1^{\text {st }}$ Cir. 1998), cert. denied, 119 S.Ct. 44 (1998)

(upholding marketing program that was a condition of receiving federal housing funds). 
might also choose to provide funds to civil rights groups to enable them to pursue integration strategies, including suing discriminatory employers or housing providers. Although the government frequently works on discrimination cases in conjunction with civil rights groups, it has never provided direct funding to these groups.

Integration, to be sure, is not as fashionable a concept today as it once was, ${ }^{289}$ but its unfashionable nature should not define its constitutional permissibility. I also believe the idea of integration is not nearly as unfashionable as it may seem; ${ }^{290}$ rather today, calls for integration come in a different form under the guise of diversity. A diverse student body, which is now generally the calling cry behind affirmative action in higher education, ${ }^{291}$ necessarily implies an integrated student body, at least at some level. Relatedly, integration has fallen out of favor largely from the current realization that meaningful integration - either in schools or in housing - now seems out of reach for much of the country, which

289 For a sampling of the extensive critical commentary see LEONARD STEINHORN \& Barb ara Diggs-Brown, By the Color of Our Skin: The Illusion of Integration and the REALITY OF RACE (1999); Wendy R. Brown, The Convergence of Neutrality and Choice: The Limits of the State's Affirmative Duty to Provide Equal Educational Opportunity, 60 TENN. L. REV. 63 (1992); Alex M. Johnson, Jr., Bid Whist, Tonk, and United States v. Fordice: Why Integrationism Fails African-Americans Again, 81 CALIF. L. REV. 1401 (1993); Gary Peller, Race Consciousness, 1990 DukE L.J. 758 (1990).

290 See, e.g., John A. Powell, Living and Learning: Linking Housing and Education, 80 MinN. L. REV. 749 (1996) (advocating integrationist strategy).

291 See Akhil Reed Amar \& Neal Kumar Kytal, Bakke's Fate, 43 UCLA L. REV. 1745 (1996) (emphasizing the importance of including student's of diverse backgrounds in higher education); Sumi K. Cho, Multiple Consciousness and the Diversity Dilemma, 68 U. Colo. L. REV. 1035 (1997) (arguing in favor of diversity as an affirmative action justification); Stephanie M. Wildman, Integration in the 1980s: The Dream of Diversity and the Cycle of Exclusion, 64 Tul. L. REV. 1625 (1990) (articulating diversity justification). 
has understandably produced a good deal of frustration and resentment among civil rights advocates. ${ }^{292}$ It is also worth highlighting one important difference between the current calls for diversity and the past calls for integration, which is that the latter were often, though not inevitably, based on an assumption of assimilation $^{293}$ whereas diversity implies preserving different cultures in a mixed culture environment.

Nevertheless, the government is certainly free to pursue integration as a social and political strategy, and at least for the near future, it is highly likely that the government will continue to treat integration as an ultimate ideal. Moreover, as was true with the set-aside programs, ${ }^{294}$ there can be no argument that a program designed to further integration would later be replaced by a program aimed at increasing segregation. An integration mandate is plainly consistent with the Fourteenth Amendment, if not mandated by its terms, ${ }^{295}$ whereas no government could contrive an argument that segregation was legitimately consistent with our constitutional dictates, and it also seems safe to suggest that no government would even try.

292 See Powell, supra note 290, at 784-87 (discussing opposition to integration among current civil rights advocates). For a measured discussion of a limited separation strategy see RoY L. BROOKS, InTEgRATION OR SEPARATION? A STRATEGy FOR RACIAL EQUALity (1996).

293 See Johnson, supra note 289, at 1469 ("The brand of integration . . practiced in America merely requires assimilation of African-Americans into white culture and does not integrate the cultures and nomos of the African-American and white communities into each other.”).

294 See text accompanying notes 263-64 supra.

295 This is the underlying rationale behind most of the Court's school desegregation cases. See, e.g., Swann v. Charlotte-Mecklenburg Board of Education, 402 U.S. 1 (1971). 


\section{CONCLUSION}

Government spending can be wielded as an important tool in the effort to eradicate societal discrimination, and if used more diligently, may save many existing, and future, programs from judicial invalidation. In this article, I have demonstrated that the Court's persistent conclusion that it is impermissible for the government to take affirmative measures to remedy societal discrimination is badly mistaken. Pursuant to the government's spending power, the government can, and does, take efforts to eradicate the social evil that is often labeled societal discrimination, just as it can take efforts to encourage women to forego abortions so long as those efforts do not rise to the level of an undue burden. With respect to its efforts to remedy societal discrimination, the government can reward its government contractors who engage in affirmative action, those contractors that have diverse workforces that may not be the product of affirmative action, and even require its contractors to seek to remedy societal discrimination by interpreting its nondiscrimination mandates to include a disparate impact claim. I do not mean to suggest that the Supreme Court would inevitably uphold all of these efforts, but the government funding cases may provide an important new element into what has otherwise become a tired and losing struggle. Moreover, by focusing on the role societal discrimination has played in the Court's doctrine, it should be clear that the government has a duty to seek its eradication, not just because of the harm it entails, but because of the role the government has played in creating and perpetuating societal discrimination. Turning to the spending power may just move that cause forward. 